\title{
25. CALCAREOUS NANNOPLANKTON CHANGES ACROSS THE CRETACEOUS/PALEOCENE BOUNDARY IN THE SOUTHERN INDIAN OCEAN (SITE 750)1
}

\author{
Thomas Ehrendorfer ${ }^{2}$ and Marie-Pierre Aubry², 3
}

\begin{abstract}
Changes in the composition of calcareous nannoplankton across the Cretaceous/Paleocene boundary at southern high-latitude Ocean Drilling Program Hole 750A are documented in this semiquantitative study. These changes are compared with changes described from other localities at high- and low-latitudes. This study provides additional data toward a detailed documentation of the paleontologic changes that occurred in the late Maestrichtian and the early Paleocene, despite limitations to the interpretation caused by coring gaps, drilling disturbance, and the presence of an unconformity at the boundary at this site.
\end{abstract}

\section{INTRODUCTION}

An almost complete section across the Cretaceous/Paleocene boundary was recovered from Ocean Drilling Program (ODP) Hole 750A located on the Southern Kerguelen Plateau, in the eastern part of the Raggatt Basin west of the deep Labuan Basin $\left(57^{\circ} 35.54^{\prime}\right.$ S, $81^{\circ} 14.42^{\prime}$ E; Fig. 1). Despite an unconformity at the boundary with a hiatus of about 0.3 m.y. (see also Zachos et al., this volume), a detailed study of the change in the calcareous nannoplankton across the boundary was undertaken because this is one of the first sites at southern high-latitudes in which the boundary was recovered. In this paper we document the changes in composition that the calcareous nannoplankton underwent and compare them with changes described from sections elsewhere, in particular from Hole $690 \mathrm{C}$, Maud Rise, Weddell Sea ( $\left.65^{\circ} 9.621^{\prime} \mathrm{S}, 1^{\circ} 12.285^{\prime} \mathrm{E}\right)$.

\section{THE BOUNDARY AT HOLE 750A}

The Cretaceous/Paleocene contact is well marked at Hole 750A (Fig. 2). A Maestrichtian white nannofossil chalk (Subunit IIIA) is overlain by a lower Paleocene, intensively bioturbated, grayish chalk that grades upward into a white chalk (Unit II) (Shipboard Scientific Party, 1989). The contact itself was strongly disturbed by drilling so that its exact nature is not known. The Maestrichtian chalk just below the contact is not homogeneously white but includes greenish gray zones with solution seams. The lower Paleocene clayey chalk just above the contact is also heterogeneous, with interfingering darker and lighter green layers. In addition, it includes clasts of Maestrichtian chalk that resulted from resedimentation rather than from bioturbation (see Fig. 2).

\section{TECHNIQUES AND METHODS}

Detailed sampling was performed on board ship using toothpicks. To identify potentially biased data resulting from drilling disturbance, strong bioturbation, resedimentation, and differential dissolution, samples were taken at close intervals on both sides of the boundary. In addition, several samples were taken from levels in which various sediment types are

\footnotetext{
${ }^{1}$ Wise, S. W., Jr., Schlich, R., et al., 1992. Proc. ODP, Sci. Results, 120: College Station, TX (Ocean Drilling Program).

2 Woods Hole Oceanographic Institution, Woods Hole, MA 02543, U.S.A.

${ }^{3}$ Centre de Paléontologie Stratigraphique et Paléoécologie, Université Claude Bernard, 27-43 Blvd. du 11 Novembre, 69622 Villeurbanne Cedex, France.
}

juxtaposed (Fig. 3). Smear slides were prepared from all samples and studied with a photomicroscope. Additional material was collected from selected levels for joint light and scanning microscope studies. The procedures described by Moshkovitz (1974) for examining the same specimen with both light microscope and scanning electron microscope were followed to establish the taxonomic framework used in this study and discussed in Aubry and Ehrendorfer (in press).

Only smear slides were used for semiquantitative analysis. For most samples over 300 specimens were counted per slide. Maestrichtian assemblages were analyzed once, but Paleocene assemblages were counted in two steps. During the first count, all nannofossils except placoliths of Prinsius spp. and fragments of thoracospheres were counted. The purpose of the second count was to determine roughly the proportions between all species recorded during the first count on the one hand and the placoliths (and coccospheres) of Prinsius spp. and fragments (and opercula) of thoracospheres on the other hand. Occasional coccospheres of Prinsius spp. were recorded as single placoliths, and rare opercula of thoracospheres were counted as fragments. All fragments that could be confidently assigned to Thoracosphaera spp. were counted. We followed this procedure because of the overwhelming dominance of Prinsius spp. and of fragments of thoracospheres in the Paleocene assemblages. While counting, all specimens within a view field were recorded.

Several rows were scanned so that areas with different concentrations of nannofossils were encountered, and biased results caused by differences in concentration were avoided (or minimized). The concentration of nannofossils in a preparation influences greatly the distribution of the calcareous nannofossils (Tables 1 and 2), with the less concentrated areas enriched in small forms. Biased counts resulting from lithologic differences were avoided by checking the extent to which the composition of the assemblages varied with lithology. Counts were made for samples taken at the same level, but from slightly different lithologies, in particular, colored differently.

As can be seen from Table 3, there is variability in the composition of Paleocene assemblages at selected levels. This variability is not necessarily a reflection of vertical bioturbation, as indicated by the absence of Cruciplacolithus primus in all samples taken at $91.5 \mathrm{~cm}$ in Section 120-750A-15R-3. When multiple counts were made on one slide, or on several slides prepared from different samples taken at the same stratigraphic level, the percentages of the calcareous nannofossils 


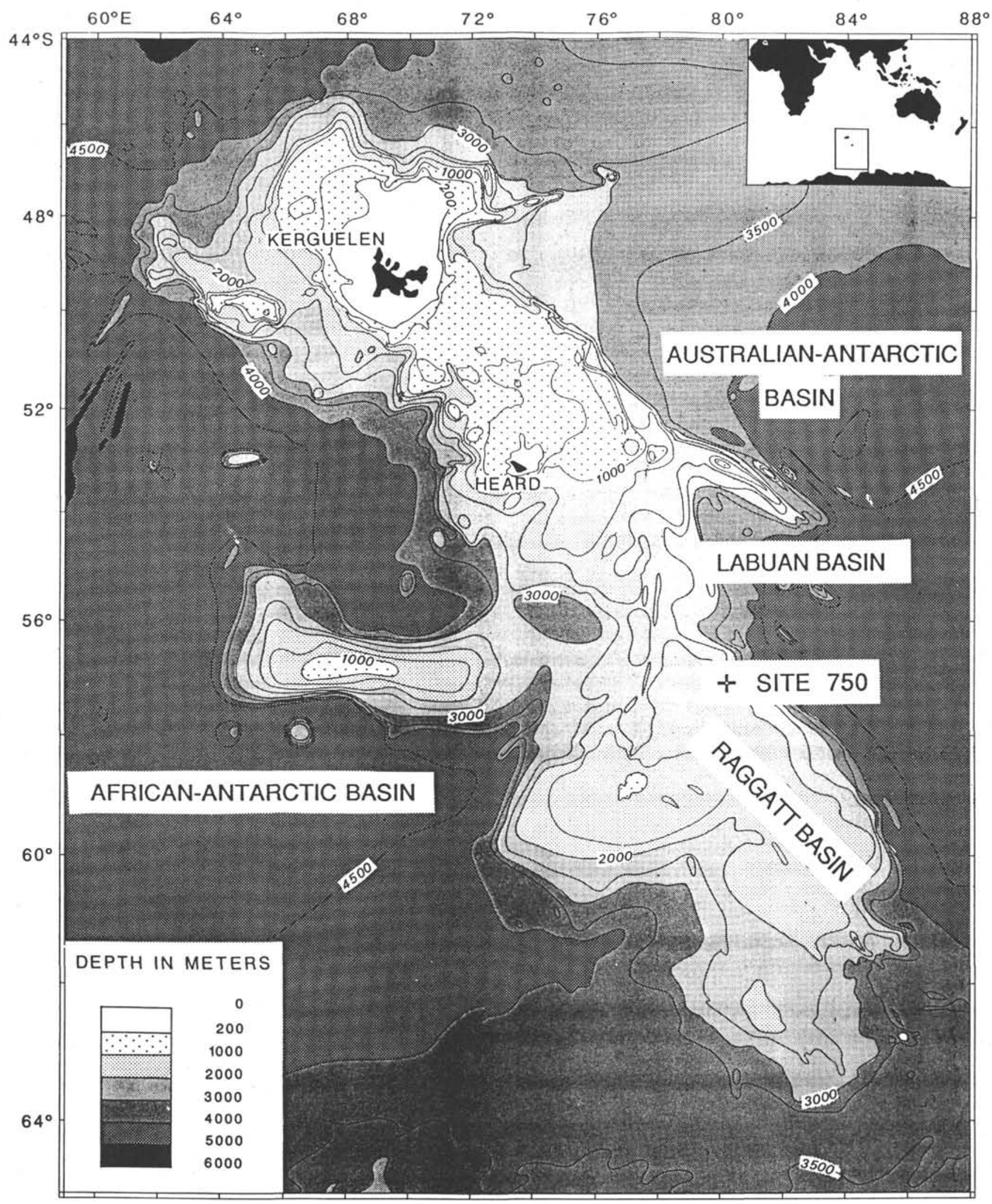

Figure 1. Location of Hole $750 \mathrm{~A}$ in the southern Indian Ocean. 
$\mathrm{cm}$

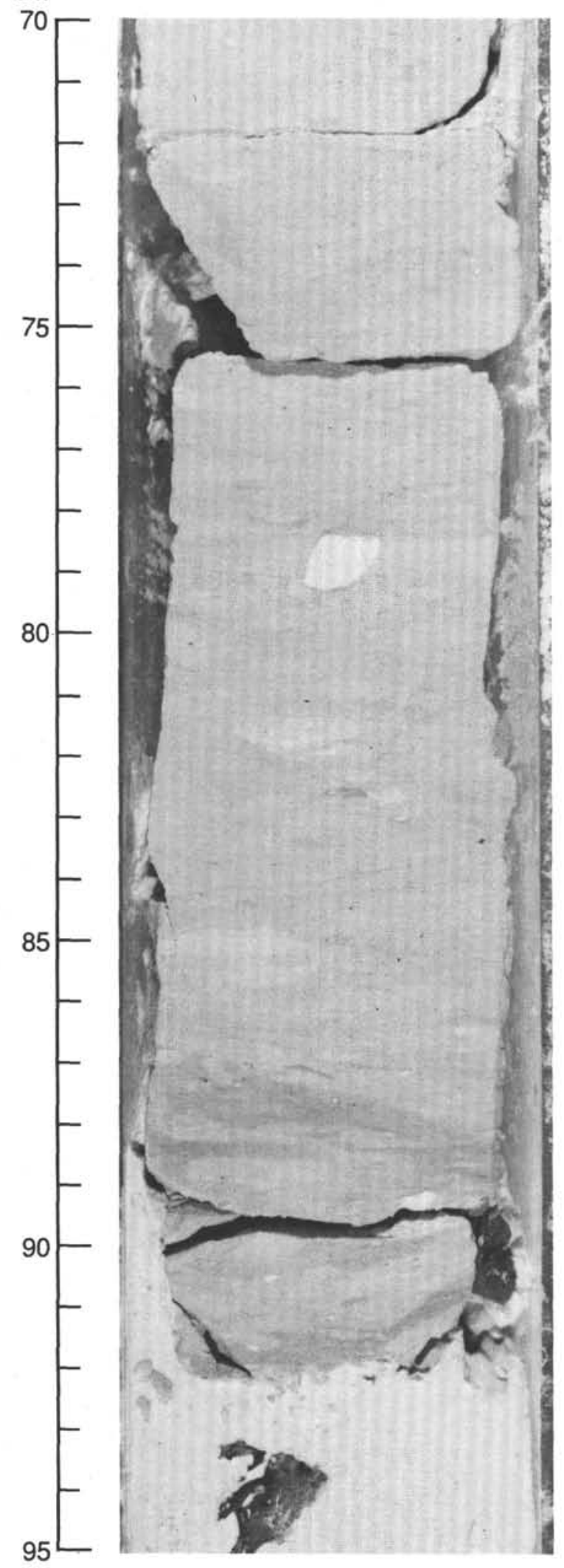

Figure 2. The lithologic contact at the Cretaceous/Paleocene boundary, Hole 750A (Section 120-750A-15R-3, $70-95 \mathrm{~cm}$ ). at this level were averaged between samples. Significant differences were observed between assemblages from the white and the gray Maestrichtian chalk (Tables 4 and 5). It should be emphasized that the method of sample preparation and the counting techniques used can only serve to delineate major trends.

\section{STRATIGRAPHY}

The Cretaceous/Paleocene contact was not only strongly disturbed by drilling; the sequence is also incomplete. Calcareous nannofossil Zone NP1 (Martini, 1971) is thin (see below), and planktonic foraminiferal Zone $\mathrm{P} \alpha$ (Blow, 1979) could not be confidently recognized, whereas Subzone P1a (Berggren and Miller, 1988) is well characterized (Zachos et al., this volume).

Magnetostratigraphy has yielded poor results in the upper Cretaceous-Paleocene section recovered from Site 750. Two normal polarity magnetozones, however, were identified in the lower Paleocene and tentatively assigned to Chrons $\mathrm{C} 28 \mathrm{~N}$ and $\mathrm{C} 27 \mathrm{~N}$ (Shipboard Scientific Party, 1989). The upper extent of these two magnetozones is not known because of poor recovery in Cores $120-750 \mathrm{~A}-12 \mathrm{R}$ to $-14 \mathrm{R}$. Their lower boundary is well-delineated so that the levels at which the presumed $\mathrm{C} 27 \mathrm{R} / \mathrm{C} 27 \mathrm{~N}$ and $\mathrm{C} 28 \mathrm{R} / \mathrm{C} 28 \mathrm{~N}$ boundaries occur are known. Using the ages estimated by Berggren et al. (1985) for these reversal boundaries, a sedimentation rate curve can be drawn tentatively (Fig. 4 and Table 6). It suggests that, had the section been continuous, the Cretaceous/Paleocene boundary would have occurred at about 356 mbsf, and that the Paleocene section missing at this site corresponds to a hiatus of about $0.3 \mathrm{~m} . \mathrm{y}$. The curve is constrained by two points only; thus, our estimate for the duration of the lower Paleocene hiatus at this site is precarious. The lower part of Zone NP1 (i.e., below the first occurrence of Cruciplacolithus primus), however, has been identified, so that the hiatus is probably not longer than $\mathbf{0 . 3}$ m.y.

Calcareous nannofossil stratigraphy of the lower Paleocene section recovered from Site 750 does not help in evaluating the identification of Chrons $\mathrm{C} 27 \mathrm{~N}$ and $\mathrm{C} 28 \mathrm{~N}$. Chron $\mathrm{C} 27 \mathrm{~N}$ is associated with the lower part of Zone NP4 (Berggren et al., 1985), but Ellipsolithus macellus does not occur at this site. The base of Chron $\mathrm{C} 28 \mathrm{~N}$ is associated with the NP2/NP3 zonal boundary (Berggren et al., 1985). The extremely rare occurrence of Chiasmolithus danicus in the upper $100 \mathrm{~cm}$ of Section $120-750$ A-15R-1 is possibly a result of bioturbation, and the NP2/NP3 zonal boundary cannot be drawn confidently.

Although the white Maestrichtian chalk belongs to the uppermost Cretaceous calcareous nannofossil Zone (the Nephrolithus frequens Zone; Cepek and Hay, 1969), it is possible that the unconformity lies in the upper part of this zone. Because of poor magnetostratigraphy and poor recovery in Cores $120-750 \mathrm{~A}-15 \mathrm{R}$ and $-16 \mathrm{R}$ (there is a $5.45-\mathrm{m}$ coring gap between the $35 \mathrm{~cm}$ of Maestrichtian chalk underlying the boundary in Core $120-750 \mathrm{~A}-15 \mathrm{R}$ and the chalk recovered in Section 120-750A-16R-1), it is not possible to determine the duration of the Cretaceous hiatus (if any) at this site.

Several toothpick samples were taken from Sample 120$750 \mathrm{~A}-15 \mathrm{R}-3,91.5 \mathrm{~cm}$. Despite long search, no specimens of Cruciplacolithus primus were found. We believe that this level represents the lower part of Zone NP1. Counts were made on four slides (Table 7) and the percentages were averaged. 


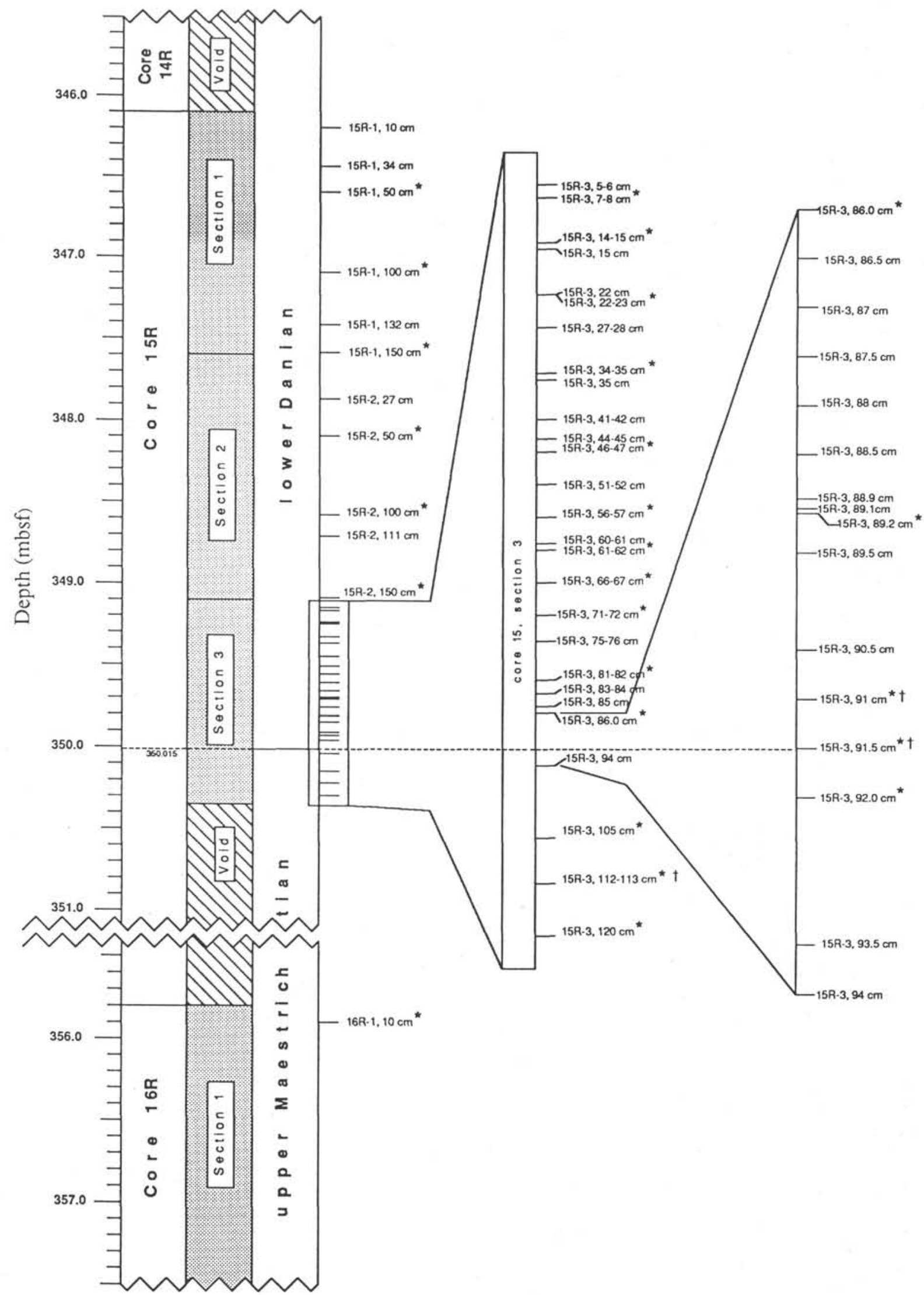

Figure 3. Stratigraphic levels sampled for this study. Dagger $(\dot{\dagger})=$ levels at which several samples were taken, and asterisk $(*)=$ levels sampled for semiquantitative analysis. 
Table 1. Influence of the density of a preparation (Sample 120-750A-15R-3, 66-67 cm) on species frequency.

\begin{tabular}{lrrr}
\hline \multicolumn{1}{c}{ Species } & $\begin{array}{c}\text { Count } 1 \\
(\%)\end{array}$ & $\begin{array}{c}\text { Count } 2 \\
(\%)\end{array}$ & $\begin{array}{c}\text { Count } 3 \\
(\%)\end{array}$ \\
\hline Biscutum castrorum & 11.3 & 7.5 & 16.9 \\
Cruciplacolithus spp. & 3.0 & 9.0 & 4.4 \\
Hornibrookina sp. cf. & & & \\
$\quad$ H. teuriensis & 25.6 & 15.8 & 12.5 \\
$\begin{array}{l}\text { Markalius inversus } \\
\text { Neocrepidolithus }\end{array}$ & 3.0 & 1.5 & 0.7 \\
$\quad$ cohenii & 1.5 & 0.8 & 2.9 \\
Placozygus sigmoides & 46.6 & 49.6 & 50.0 \\
Cretaceous species & 6.0 & 9.0 & 8.1 \\
Undetermined & 3.0 & 6.8 & 4.4 \\
\hline
\end{tabular}

Note: Count 1 performed on areas of low density, Count 2 performed on areas of high density, and Count 3 performed on areas of average density.

Table 2. Influence of the density of a preparation (Sample 120-750A-15R-3, 56-57 cm) on species frequency.

\begin{tabular}{lrr}
\hline \multicolumn{1}{c}{ Species } & $\begin{array}{c}\text { Count } 1 \\
(\%)\end{array}$ & $\begin{array}{c}\text { Count } 2 \\
(\%)\end{array}$ \\
\hline Biscutum castrorum & 11.2 & 10.5 \\
Cruciplacolithus spp. & 20.7 & 21.7 \\
Hornibrookina sp. cf. & & \\
$\quad$ H. teuriensis & 8.8 & 11.7 \\
Markalius inversus & 3.6 & 2.8 \\
Neocrepidolithus cohenii & 6.0 & 3.5 \\
Placozygus sigmoides & 34.5 & 35.7 \\
Cretaceous species & 5.7 & 3.3 \\
Undetermined & 9.5 & 10.7 \\
\hline
\end{tabular}

Note: Consistent results are obtained when areas of different densities are included in each count.

\section{CALCAREOUS NANNOFOSSIL ASSEMBLAGES AROUND THE CRETACEOUS/PALEOCENE BOUNDARY}

Figures 5-8 show the profound changes that calcareous nannofossil assemblages underwent across the boundary. The plot (Fig. 5) of the distribution of the calcareous nannofossil species in the samples studied is intended to provide the detailed stratigraphic ranges of taxa throughout Core 120$750 \mathrm{~A}-15 \mathrm{R}$, and, combined with Figures $6-8$, to illustrate the frequency of these taxa. Percival and Fischer (1977) and Perch-Nielsen et al. (1982) recognized that three groups of species can be distinguished in early Paleocene calcareous nannofossil assemblages.

Percival and Fischer (1977) referred to them as "vanishing species," "persistent species," and "incoming species"; Perch-Nielsen et al. (1982) referred to them as "Cretaceous species," "survivors," and "Tertiary species." We have chosen to follow the terminology proposed by Percival and Fischer but at the genus level rather than at the species level for reasons given in Aubry (1989, 1990, and unpubl. data). She showed that, for calcareous nannofossils, the genus is a less "superficial" taxon (i.e., having a phylogenetic meaning) than the species itself (i.e., mostly restricted to a morphotype). The groups "vanishing" and "Cretaceous" species are clearly synonymous, but the groups "incoming", and "Tertiary" species, on the one hand, and "survivors" and "persistent" species, on the other, may differ slightly.
Perch-Nielsen et al. (1982) regard as incoming species all forms that evolved shortly after the boundary, even those that share the same structure with the survivors (and thus represent the same genera as these latter). We do not know if Percival and Fischer (1977) would have included such taxa among the incoming species or among the persistent species because the taxonomic scheme available at the time of their study was limited. Their inclusion of Braarudosphaera discula among the incoming species suggests, however, that they would have made the same choice as Perch-Nielsen et al. (1982).

In the vanishing genera are included the vanishing species sensu Percival and Fischer (1977) and the Cretaceous species sensu Perch-Nielsen et al. (1982). The species assigned to genera that are represented in both the Cretaceous and the Paleocene are included among the persistent genera. This concept differs noticeably from that of survivors sensu PerchNielsen et al. (1982). The species Biscutum castrorum, which occurs in the Cretaceous, and the early Paleocene form Biscutum kerguelensis, are both assigned to the persistent genera, whereas the former would belong to the survivors, the latter to the incoming species following Perch-Nielsen et al. (1982). Likewise, the concept of incoming genera differs from that of Tertiary species. The Appendix indicates to what group the species encountered during this study are assigned. Discussions on the taxonomy and illustrations of these forms are given in Aubry and Ehrendorfer (in press).

An abrupt change in the composition of the calcareous nannoflora is seen across the Cretaceous/Paleocene boundary at Hole $750 \mathrm{~A}$, as a result of a dramatic decrease in the abundance of the vanishing genera and the resulting dominance of the persistent genera (Fig. 6). A second abrupt change occurs $70 \mathrm{~cm}$ above the boundary (between Samples 120-750A-15R-3, 34-35 and $22-23 \mathrm{~cm})$. From this level upward the incoming genera become predominant, the persistent genera constitute a small fraction of the assemblages, and the frequency of the vanishing genera is extremely reduced. In the interval between these changes (between 350.0 and $349.3 \mathrm{mbsf}$ ), the incoming and persistent genera are about equally represented but the vanishing genera decrease rapidly in abundance.

There is no doubt that the abruptness of the change at 350.0 mbsf across the Cretaceous/Paleocene boundary is artificially enhanced because of the unconformable contact. There is no reason, however, to question the reality of the second sharp change in composition that occurs at about 349.30 mbsf. Using the tentative sedimentation rate curve (Fig. 4), this latter change occurred at about $65.9 \mathrm{Ma}$ (i.e., this change is $0.5 \mathrm{~m} . \mathrm{y}$. younger than the boundary). The level at which the frequency of the incoming genera begins to increase is essentially correlative with the lowest occurrence of Cruciplacolithus primus (about $0.3 \mathrm{~m} . \mathrm{y}$. after the boundary).

\section{The Vanishing Genera}

The vanishing genera are represented by the same species below and above the boundary. They are extremely rare above $349.10 \mathrm{mbsf}$, except at 347.60 mbsf where Lucianorhabdus cayeuxii is common (Fig. 7).

\section{The Persistent Genera}

Of the persistent genera only the genus Placozygus is represented in the Upper Cretaceous. Placozygus fibuliformis constitutes up to $5 \%$ of the Late Cretaceous assemblages (Fig. 7). Placozygus sigmoides does not occur in the Upper Cretaceous chalk, but it is extremely common in the lower $\mathrm{Pa}$ leocene and reaches percentages higher than $50 \%$ (Fig. 7; Tables 8-10). The frequency of Biscutum castrorum, which reaches almost $20 \%$ in Sample $120-750$ A-15R-3, $89.2 \mathrm{~cm}$, 
Table 3. Influence of lithology on species frequency in the Paleocene clayey chalk.

\begin{tabular}{|c|c|c|c|c|c|c|}
\hline Sample 120-750A-15R-3, $91 \mathrm{~cm}$ & \multicolumn{2}{|c|}{$\begin{array}{l}\text { Darker green } \\
\text { Number of }\end{array}$} & $\begin{array}{l}\text { Lighter } \\
\text { Number of } \\
\text { specimens }\end{array}$ & $\begin{array}{r}\text { green } \\
\% \\
\end{array}$ & $\begin{array}{l}\text { Indif } \\
\text { Number of } \\
\text { specimens }\end{array}$ & $\begin{array}{r}\text { rent } \\
\% \\
\end{array}$ \\
\hline Incoming taxa: & & & & & & \\
\hline Cruciplacolithus spp. & 1 & 0.3 & 8 & 1.9 & 16 & 5.1 \\
\hline $\begin{array}{l}\text { Hornibrookina sp. cf. H. teuriensis } \\
\text { Persistent taxa: }\end{array}$ & 26 & 8.2 & 31 & 7.3 & 31 & 9.9 \\
\hline Biscutum castrorum & 61 & 19.3 & 39 & 9.1 & 39 & 12.4 \\
\hline Markalius inversus & 13 & 4.1 & 9 & 2.1 & 10 & 3.2 \\
\hline Neocrepidolithus cohenii & 8 & 2.5 & 4 & 0.9 & 4 & 1.3 \\
\hline Placozygus fibuliformis & 2 & 0.6 & & & & \\
\hline Placozygus sigmoides & 85 & 26.9 & 107 & 25.1 & 106 & 33.8 \\
\hline Vanishing taxa: & & & & & & \\
\hline Ahmuellerella octoradiata & 2 & 0.6 & 7 & 1.6 & 1 & 0.3 \\
\hline Arkhangelskiella cymbiformis & 3 & 0.9 & 9 & 2.1 & 4 & 1.3 \\
\hline Cretarhabdus spp. & 1 & 0.3 & 1 & 0.2 & 3 & 1.0 \\
\hline Cribrosphaerella ehrenbergii & 2 & 0.6 & 3 & 0.7 & 1 & 0.3 \\
\hline Eiffellithus turriseiffeli & 1 & 0.3 & 2 & 0.5 & & \\
\hline Glaukolithus fessus & 1 & 0.3 & 7 & 1.6 & 3 & 1.0 \\
\hline Kamptnerius magnificus & 8 & 2.5 & 19 & 4.4 & 5 & 1.6 \\
\hline Lucianorhabdus cayeuxii & 15 & 4.7 & 37 & 8.7 & 15 & 4.8 \\
\hline Microrhabdulus decoratus & & & 4 & 0.9 & & \\
\hline Micula staurophora & 1 & 0.3 & 1 & 0.2 & 1 & 0.3 \\
\hline Nephrolithus frequens & 20 & 6.3 & 26 & 6.1 & 16 & 5.1 \\
\hline Prediscosphaera cretacea & 4 & 1.3 & 15 & 3.5 & 4 & 1.3 \\
\hline Prediscosphaera spinosa & & & 2 & 0.5 & 2 & 0.6 \\
\hline Prediscosphaera stoveri & 53 & 16.8 & 86 & 20.1 & 41 & 13.1 \\
\hline Undetermined & 9 & 2.8 & 10 & 2.3 & 12 & 3.8 \\
\hline Sum & 316 & 100.0 & 427 & 100.0 & 314 & 100.0 \\
\hline
\end{tabular}

Note: Counts were performed on preparations made from three samples taken at $91 \mathrm{~cm}$ in Section $120-750 \mathrm{~A}-15 \mathrm{R}-3$ in sediments of darker green, lighter green, and intermediate colors.

decreases progressively upward through Core 120-750A-15R. Markalius inversus and Neocrepiodolithus cohenii represent minor components of the early Paleocene assemblages (Fig. 7). Fragments of Thoracosphaera spp. constitute the bulk (as much as $80 \%$ ) of the assemblages in the lower part of the Paleocene section.

\section{The Incoming Genera}

Hornibrookina sp. cf. H. teuriensis forms a high percentage (over $15 \%$ ) of the calcareous nannofossil assemblages in the lowermost Paleocene (upper part of Zone NP1) recovered from Hole 750A (Fig. 7; Tables 8-10). Jiang and Gartner (1986) and Pospichal and Wise (1990) reported on the occurrence of $H$. teuriensis from the Brazos River section (Texas) and of $H$. edwardsii from Site 690 (Maud Rise, Weddell Sea), respectively, in the lowermost Paleocene. These reports and ours indicate that the frequency of $\mathrm{H}$. teuriensis in earliest Paleocene assemblages varies with latitude, from scarce at low latitudes to abundant at high latitudes.

The increase in abundance of Cruciplacolithus spp. occurs in a sawtooth fashion. Because of poor preservation (obscured central area), it was not possible to distinguish consistently between different species.

At 349.35 mbsf, assemblages are flooded with the tiny placoliths and coccospheres of Prinsius tenuiculum and possibly $P$. dimorphosus (Fig. 8). In the counts these two forms were not distinguished. The abundance of $P$. tenuiculum is generally high above this level, but it is not clear whether abrupt, strong fluctuations are related to changes in preservation, or whether they can be regarded as a primary indicator of unstable paleoceanographic conditions. Other incoming taxa such as Biantholithus sparsus, Coccolithus pelagicus, and Ericsonia subpertusa remain scarce.

\section{DISCUSSION}

In recent years, semiquantitative studies documenting the changes that the calcareous nannoplankton underwent across the Cretaceous/Paleocene boundary have become available (Percival and Fischer, 1977; Romein, 1977; Monechi, 1979; PerchNielsen, 1979a, 1979b; Herm et al., 1981; Romein and Smit, 1981; Thierstein, 1981; Jiang and Gartner, 1986; Pospichal and Wise, 1990). Most of them, however, concern sections geo- 
Table 4. Influence of lithology on species frequency in the Maestrichtian chalk.

\begin{tabular}{|c|c|c|c|c|}
\hline \multirow{2}{*}{ Sample 120-750A-15R-3, 112-113 cm } & \multicolumn{2}{|c|}{ White chalk } & \multicolumn{2}{|c|}{ Grey chalk } \\
\hline & $\begin{array}{l}\text { Number of } \\
\text { specimens }\end{array}$ & $\%$ & $\begin{array}{l}\text { Number of } \\
\text { specimens }\end{array}$ & $\%$ \\
\hline $\begin{array}{l}\text { Persistent taxa: } \\
\text { Neocrepidolithus cohenii } \\
\text { Vanishing taxa: }\end{array}$ & 年 & 2.0 & 3 & 0.9 \\
\hline Ahmuellerella octoradiata & 6 & 1.7 & 2 & 0.6 \\
\hline Arkhangelskiella cymbiformis & 37 & 10.6 & 31 & 9.6 \\
\hline Cretarhabdus spp. & 5 & 1.4 & 2 & 0.6 \\
\hline Cribrosphaerella ehrenbergii & 1 & 0.3 & 1 & 0.3 \\
\hline Eiffellithus turriseiffeli & 1 & 0.3 & & \\
\hline Glaukolithus fessus & 17 & 4.9 & 2 & 0.6 \\
\hline Kamptnerius magnificus & 21 & 6.0 & 28 & 8.7 \\
\hline Lucianorhabdus cayeuxii & 53 & 15.2 & 61 & 18.9 \\
\hline Microrhabdulus decoratus & 2 & 0.6 & & \\
\hline Micula staurophora & 10 & 2.9 & 26 & 8.1 \\
\hline Nephrolithus frequens & 43 & 12.3 & 35 & 10.9 \\
\hline Prediscosphaera cretacea & 23 & 6.6 & 18 & 5.6 \\
\hline Prediscosphaera spinosa & 1 & 0.3 & 4 & 1.2 \\
\hline Prediscosphaera stoveri & 105 & 30.1 & 91 & 28.3 \\
\hline Watznaueria barnesae & & & 3 & 0.9 \\
\hline Undetermined & 17 & 4.9 & 15 & 4.7 \\
\hline Sum & 349 & 100.0 & 322 & 100.0 \\
\hline Fields examined & 48 & & 102 & \\
\hline
\end{tabular}

Notes: Counts were performed on two samples taken at 112-113 cm in Section 120-750A-15R-3: one in the white chalk, one in the greenish chalk. In this experiment, only unbroken nannofossils were counted. Species frequencies are comparable except for a decrease in " $G$. fessus" and an enrichment (slight) in $L$. cayeuxii and (strong) in $M$. staurophora in the gray chalk. However, twice as many fields were counted in the gray chalk to obtain a comparable number of unbroken coccoliths from both samples.

graphically distant but all from low latitudes. There are only a few reports dealing with high-latitude sections (Perch-Nielsen, 1979 b; Perch-Nielsen et al., 1982) and only one study of a southern high-latitude site (Pospichal and Wise, 1990).

Perch-Nielsen et al. (1982) pointed out some of the differences observed in the calcareous nannofossil assemblages between low and high latitudes. As at other high-latitude localities (e.g., Stevens Klint section, Denmark: Perch-Nielsen, 1979b; DSDP Site 524: Perch-Nielsen et al., 1982; ODP Sites 690 and 752: Pospichal, 1989) and in contrast with low-latitude sections, no Thoracosphaera occurs in the Maestrichtian assemblages from Hole 750A. As in other high-latitude sites (e.g., Denmark: Perch-Nielsen, 1979b; ODP Site 690: Pospichal and Wise, 1990), Placozygus sigmoides is common above the boundary. This species is rare in early Paleocene assemblages from low-latitude regions (e.g., Biarritz: Perch-Nielsen, 1979c; Gubbio: Monechi, 1979; Zumaya: Percival and Fischer, 1977). Braarudosphaera bigelowii is absent at Hole $750 \mathrm{~A}$, although it is particularly abundant in the lower Paleocene of the Brazos River section (Texas: Jiang and Gartner, 1986), the Braggs section (Alabama: Thierstein, 1981), in the Rio Urola and Punta de San Telmo sections (Spain: Percival and Fischer, 1977), and at DSDP Sites 356 (South Atlantic; paleolatitude of $31^{\circ}$ to $32^{\circ} \mathrm{S}$ at the end of the Cretaceous; Thierstein 1981) and 384 (North Atlantic; paleolatitude of about $33^{\circ} \mathrm{N}$ at the end of the Cretaceous; Thierstein, 1981).
Although successive species dominance was observed at low-latitude sites (particularly well illustrated by Monechi [1979] for Gubbio [Italy], by Romein [1977] for the Gredero section [Caravaca, southeast Spain], and by Thierstein [1981] for the Braggs section [Alabama]), no clear successive dominances are seen at Site 750 , possibly the result of the incompleteness of this Cretaceous/Paleocene sequence. Hornibrookina sp. cf. H. teuriensis is common at the base of the lower Paleocene part of the section and is replaced upward by Cruciplacolithus spp., which reaches $80 \%$ of the assemblages (exclusive of Thoracosphaera and Prinsius). A similar pattern was observed at Hole 690C (Pospichal and Wise, 1990), where a peak in abundance of Hornibrookina edwardsii (= Hornibrookina sp. cf. H. teuriensis herein) precedes a frequency increase in Cruciplacolithus primus/ tenuis. Because Site 690 is located in the Atlantic sector $\left(1^{\circ} 12.285^{\prime} \mathrm{E}\right)$ and Site 750 in the Indian Ocean sector $\left(81^{\circ} 14.42^{\prime} \mathrm{E}\right)$ of the Southern Ocean, this succession appears to have a regional significance; and the frequency peak in Hornibrookina sp. cf. H. teuriensis at both sites may be correlative. It should be noted, however, that before the abundance increase in Hornibrookina sp. cf. H. teuriensis, there is no successive dominance of the persistent species at Site 690 (Pospichal and Wise 1990). As at Site 690, Prediscosphaera stoveri is very common in the Upper Cretaceous assemblages described in this study. 
Table 5. Influence of lithology on species frequency in the Maestrichtian chalk.

\section{Sample 120-750A-15R-3, $112-113 \mathrm{~cm}$}

\section{Numbers of specimens}

$\begin{array}{ccc}\text { Nannofossils: } & \begin{array}{c}\text { White } \\ \text { chalk }\end{array} & \begin{array}{c}\text { Grey } \\ \text { chalk }\end{array} \\ \text { Whole } & 178 & 104 \\ \text { Fragments } & 72 & 57\end{array}$

Lucianorhabdus cayeuxii:

$\begin{array}{lrr}\text { Whole } & 66 & 78 \\ \text { Fragments } & 94 & 195\end{array}$

\section{Fragmentation ratio}

\author{
Nannofossils
}

Fragments/whole

$$
\begin{aligned}
& \text { White } \\
& \text { chalk }
\end{aligned}
$$

Grey

\section{L. cayeuxii}

$$
\text { Fragments/whole }
$$

Notes: Counts were performed on two samples taken at $112-113 \mathrm{~cm}$ in Section 120-750A-15R-3: one in the white chalk, one in the greenish chalk. In this experiment, broken nannofossils were recorded as well. These counts reveal an artificial enrichment in $L$. cayeuxii in the gray chalk as a result of intensive dissolution. A comparison of the results in Tables 4 and 5 call for cautious sampling before proceeding to semiquantitative analyses.

\section{CONCLUSIONS}

Interpretation of the data presented here is restricted because of drilling disturbance, coring gaps, and an unconformity at the Cretaceous/Paleocene boundary at Site 750 . As a result, this study does not bring new evidence for the ongoing discussion about the abruptness of the extinction at the Cretaceous/Paleocene boundary. The distribution pattern of the nannofossil species at this site is similar to that described from the high-latitude Cretaceous/Paleocene boundary section at Hole 690C (Pospichal and Wise, 1990). In addition, the changes seen across the boundary at this southern highlatitude site $\left(57^{\circ} 35.54^{\prime} \mathrm{S}\right)$ are similar to those described for northern high-latitude localities.

Despite its restricted character, this study brings additional data toward a much needed detailed analysis of the changes that the calcareous nannoplankton underwent across the Cretaceous/Paleocene boundary.

\section{ACKNOWLEDGMENTS}

We are thankful to the master and crew of the Joides Resolution for their cooperation and assistance on board ship; to K. von Salis Perch-Nielsen, Ellen Thomas, S. W. Wise, H. Thierstein, and A.J.T. Romein for their critical comments on an early draft of this paper. Part of this work was supported by a grant from ODP France. This is Woods Hole Oceanographic Institution Contribution No. 7519.

\section{REFERENCES}

Aubry, M.-P., 1989. Phylogenetically based calcareous nannofossil taxonomy: implications for the interpretation of geological events. In Crux, J. A., and van Heck, S. E. (Eds.), Nannofossils and Their Applications: Chichester, England (Ellis Horwood), 21-40.

1990. Calcareous nannoplankton evolution across the Cretaceous/Paleogene boundary. Geol. Soc. Am. Abstr. Programs, 22(7):A107.

Aubry, M.-P., and Ehrendorfer, T., in press. Taxonomic revision of a few poorly known Late Cretaceous-early Paleocene calcareous nannofossil species. Micropaleontology.

Berggren, W. A., Kent, D. V. and Flynn, J. J., 1985. Jurassic to Paleogene: Part 2. Paleogene geochronology and chronostratigraphy. In Snelling, N. J. (Ed.), The Chronology of the Geological Record. Geol. Soc. London Mem., 10:141-195.

Berggren, W. A., and Miller, K. G., 1988. Paleogene tropical planktonic foraminiferal biostratigraphy and magnetobiochronology. Micropaleontology, 34:362-380.

Blow, W. H., 1979. The Cainozoic Globigerinida: Leiden (E. J. Brill).

Čepek, P., and Hay, W. W., 1969. Calcareous nannoplankton and biostratigraphic subdivision of the Upper Cretaceous. Trans. Gulf Coast Assoc. Geol. Soc., 19:323-336.

Herm, D., von Hillebrandt, A., and Perch-Nielsen, K., 1981. Die Kreide/Tertiär-Grenze im Lattengebirge (Nördliche Kalkalpen) in mikropaläontologischer Sicht. Geol. Bavarica, 82:319-344.

Jiang, M. J., and Gartner, S., 1986. Calcareous nannofossil succession across the Cretaceous/Tertiary boundary in east-central Texas. Micropaleontology, 32:232-255.

Kent, D. V., and Gradstein, F. M., 1985. A Cretaceous and Jurassic geochronology. Geol. Soc. Am. Bull., 96: 1419-1427.

Martini, E., 1971. Standard Tertiary and Quaternary calcareous nannoplankton zonation. In Farinacci, A. (Ed.), Proceedings of the Second International Conference on Planktonic Microfossils, Roma: Rome (Ed. Technoscienza), 2:739-785.

Monechi, S., 1979. Variations in nannofossil assemblage at the Cretaceous/Tertiary boundary in the Bottaccione section (Gubbio, Italy). In Birkelund, T., and Bromley, R. G. (Eds.), Proceedings of the Cretaceous/Tertiary Boundary Events Symposium (Vol. II): Copenhagen (Univ. of Copenhagen), 164-169.

Moshkovitz, S., 1974. A new method for observing the same nannofossil specimens both by light microscope and scanning electron microscope and preservation of types. Isr. J. Earth Sci., 23:145-147.

Perch-Nielsen, K., 1979a. Calcareous nannofossil zonation at the Cretaceous/Tertiary boundary in Denmark. In Birkelund, T., and Bromley, R. G. (Eds.), Proceedings of the Cretaceous/Tertiary Boundary Events Symposium (Vol. I): Copenhagen (Univ. of Copenhagen), 115-135.

1979b. Calcareous nannofossils in Cretaceous/Tertiary boundary sections in Denmark. In Birkelund, T., and Bromley, R. G. (Eds.), Proceedings of the Cretaceous/Tertiary Boundary Events Symposium (Vol. II): Copenhagen (Univ. of Copenhagen), $120-126$.

1979c. Calcareous nannofossils at the Cretaceous/Tertiary boundary near Biarritz, France. In Birkelund, T., and Bromley, R. G. (Eds.), Proceedings of the Cretaceous/Tertiary Boundary Events Symposium (Vol. II): Copenhagen (Univ. of Copenhagen), 151-155.

Perch-Nielsen, K., McKenzie, J. A., and He, Q., 1982. Biostratigraphy and isotope stratigraphy and the "catastrophic" extinction of calcareous nannoplankton at the Cretaceous/Tertiary boundary. Spec. Pap., Geol. Soc. Am., 190:353-371.

Percival, S. F., and Fischer, A. G. 1977. Changes in calcareous nannoplankton in the Cretaceous-Tertiary biotic crisis at Zumaya, Spain. Evol. Theory, 2:1-35.

Pospichal, J. J., 1989. Southern high-latitude K/T boundary calcareous nannofossils from ODP Sites 690 and 752 . INA Newsl., 11:90-92.

Pospichal, J. J., and Wise, S. W., Jr., 1990. Calcareous nannofossils across the K/T boundary, ODP Hole $690 \mathrm{C}$, Maud Rise, Weddell Sea. In Barker, P. F., Kennett, J. P., et al., Proc. ODP, Sci. Results, 113: College Station, TX (Ocean Drilling Program), 515-532. 
Romein, A.J.T., 1977. Calcareous nannofossils from the Cretaceous Tertiary boundary interval in the Barranco del Gredero (Caravaca, Prov. Murcia, S.E. Spain), I. Proc. K. Ned. Akad. Wet., Ser. B: Paleontol., Geol., Phys., Chem., Anthropol., 80:256-279.

Romein, A.J.T., and Smit, J., 1981. Carbon-oxygen stable isotope stratigraphy of the Cretaceous/Tertiary boundary interval: data from the Biarritz section (SW France). Geol. Mijnbouw, 60:541-544.

Shipboard Scientific Party, 1989. Site 750. In Schlich, R., Wise, S. W., Jr., et al., Proc. ODP, Init. Repts., 120: College Station, TX (Ocean Drilling Program), 277-337.

Thierstein, H. R., 1981. Late Cretaceous nannoplankton and the change at the Cretaceous/Tertiary boundary. Spec. Publ. Soc. Econ. Paleontol. Mineral., 32:355-394.

Date of initial receipt: 26 February 1990

Date of acceptance: 30 August 1990

Ms 120B-148

\section{APPENDIX}

Taxonomy and Species Assignments to the Incoming, Persistent, and Vanishing Genera for This Study

\section{Incoming Genera}

Biantholithus sparsus Bramlette and Martini, 1964

Chiasmolithus danicus (Brotzen, 1959) Hay and Mohler, 1967

Coccolithus pelagicus (Wallich, 1877) Schiller, 1930

Cruciplacolithus primus Perch-Nielsen, 1977

Cruciplacolithus tenuis (Stradner, 1961) Hay and Mohler in Hay et al., 1967

Cruciplacolithus Hay and Mohler in Hay et al., 1967, spp. indet.

Ericsonia cava (Hay and Mohler, 1967) Perch-Nielsen, 1969

Ericsonia subpertusa Hay and Mohler, 1967

Hornibrookina Edwards, 1973, cf. H. teuriensis Edwards, 1973

Prinsius martinii (Perch-Nielsen, 1969) Haq, 1971

Prinsius tenuiculum (Okada and Thierstein, 1979) Perch-Nielsen, 1984

Prinsius dimorphosus (Perch-Nielsen, 1969) Perch-Nielsen, 1977

\section{Persistent Genera}

Biscutum castrorum Black in Black and Barnes, 1959

Biscutum kerguelensis Aubry, 1991

Cyclagelosphaera margerelii Nol, 1965
Ellipsagelosphaera Noël, 1965, sp. indet.

Goniolithus fluckigeri Deflandre, 1957

Lapideacassis blackii Perch-Nielsen in Perch-Nielsen and Franz, 1977

Markalius inversus (Deflandre in Deflandre and Fert, 1954) Bramlette and Martini, 1964

Neocrepidolithus cohenii (Perch-Nielsen, 1968) Perch-Nielsen, 1984

Placozygus fibuliformis (Reinhardt, 1964) Hoffmann, 1970

Placozygus sigmoides (Bramlette and Sullivan, 1961) Romein, 1979

Scampanella asymmetrica Perch-Nielsen, 1977

Scampanella bispinosa Perch-Nielsen, 1977

Scampanella wisei Perch-Nielsen in Perch-Nielsen and Franz, 1977

Scampanella Forchheimer and Stradner, 1973 emend. Perch-Nielsen and Franz, 1977, sp. indet.

Thoracosphaera operculata Bramlette and Martini, 1964

Thoracosphaera sp. cf. T. imperforata Kamptner, 1927

\section{Vanishing Genera}

Ahmuellerella octoradiata (Gorka, 1957) Reinhardt, 1964

Arkhangelskiella cymbiformis Vekshina, 1959

Cretarhabdus conicus Bramlette and Martini, 1964

Cretarhabdus crenulatus Bramlette and Martini, 1964

Cretarhabdus Bramlette and Martini, 1964, spp. indet.

Cribrosphaerella ehrenbergii (Arkhangelsky, 1912) Deflandre in Piveteau, 1952

Eiffellithus turriseiffeli (Deflandre in Deflandre and Fert, 1954) Reinhardt, 1965

Glaukolithus fessus (Stover, 1966) Perch-Nielsen, 1968

Kamptnerius magnificus Deflandre, 1959

Lithastrinus floralis Stradner, 1962

Lucianorhabdus cayeuxii Deflandre, 1959

Microrhabdulus decoratus Deflandre, 1959

Micula staurophora (Gardet, 1955) Stradner, 1963

Nephrolithus frequens Gorka, 1957

Prediscosphaera cretacea (Arkhangelsky, 1912) Gartner, 1968

Prediscosphaera spinosa (Bramlette and Martini, 1964) Gartner, 1968

Prediscosphaera stoveri (Perch-Nielsen, 1968) Shafik and Stradner, 1971

Reinhardtites anthophorus (Deflandre, 1959) Perch-Nielsen, 1968

Reinhardtites levis Prins and Sissingh in Sissingh, 1977

Rhagodiscus Reinhardt, 1967, spp. indet.

Watznaueria barnesae (Black in Black and Barnes, 1959) PerchNielsen, 1968 


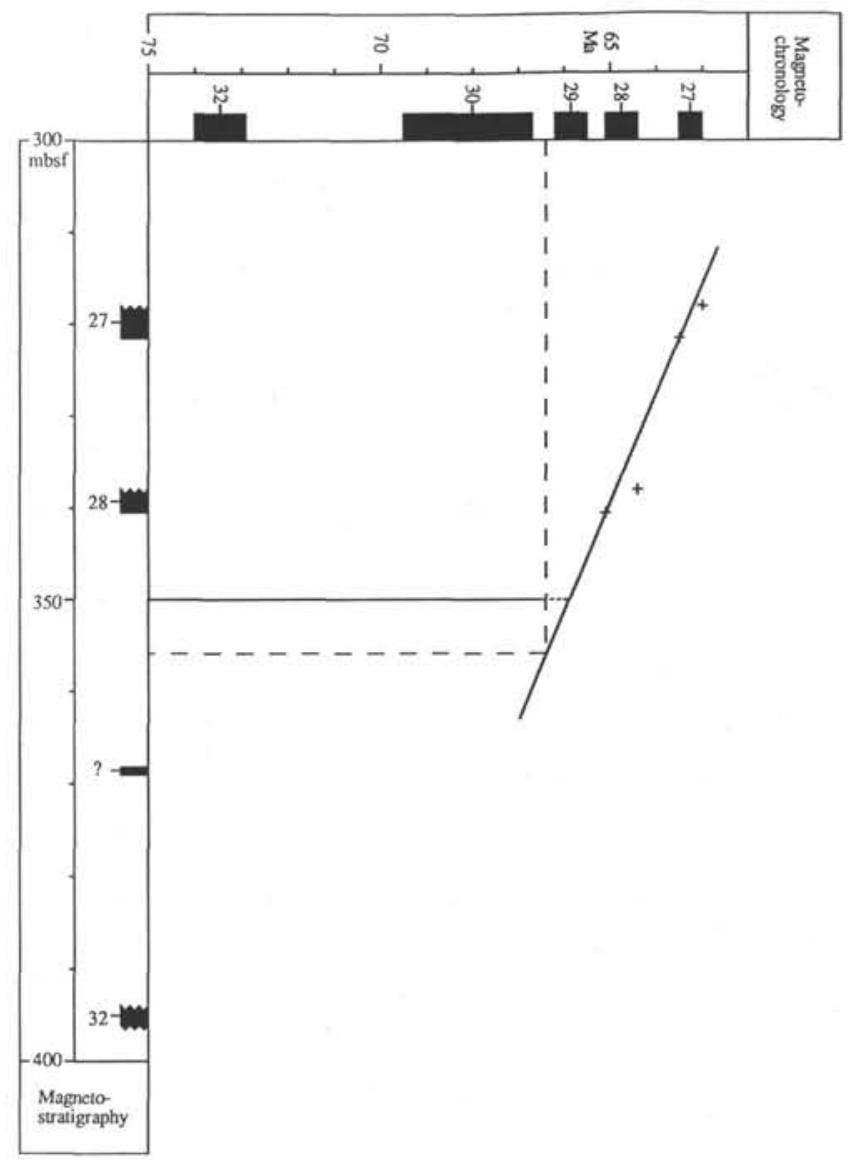

Figure 4. Tentative sedimentation rate curve for the lower Paleocene sequence recovered at Hole 750A. Magnetobiochronology from Berggren et al. (1985) and Kent and Gradstein (1985). Magnetostratigaphy from Heider (this volume).

Table 6.

\begin{tabular}{cccc}
\hline Chron & Age (Ma) & $\begin{array}{c}\text { Depth in core } \\
\text { (mbsf) }\end{array}$ \\
\hline $27 \mathrm{~N}$ & y & 63 & $318.25(+)$ \\
& o & 63.5 & 321.82 \\
$28 \mathrm{~N}$ & y & 64.4 & $337.86(+)$ \\
& o & 65.1 & 340.52 \\
$29 \mathrm{~N}$ & y & 65.5 & \\
& o & 66.2 & \\
$30 \mathrm{~N}$ & y & 66.7 & \\
& o & 69.5 & \\
$32 \mathrm{~N}$ & y & 73 & $394.10(+)$ \\
& o & 74 & $396.20(+)$ \\
\hline
\end{tabular}

Note: Age estimates are from Berggren et al. (1985) and Kent and Gradstein (1985). Depth in core is from Heider et al. (this volume). $y=$ younger boundary and $o=$ older boundary. 
Table 7. Species frequencies in sediments assigned to the lower part of Zone NP1 at Hole 750A.

\begin{tabular}{|c|c|c|c|c|c|c|c|c|}
\hline \multirow{2}{*}{ Sample 120-750A-15R-3, $91.5 \mathrm{~cm}$} & \multicolumn{2}{|c|}{ A } & \multicolumn{2}{|c|}{ B } & \multicolumn{2}{|c|}{ C } & \multicolumn{2}{|c|}{ D } \\
\hline & $\begin{array}{l}\text { Number of } \\
\text { specimens }\end{array}$ & $\%$ & $\begin{array}{l}\text { Number of } \\
\text { specimens }\end{array}$ & $\%$ & $\begin{array}{l}\text { Number of } \\
\text { specimens }\end{array}$ & $\%$ & $\begin{array}{l}\text { Number of } \\
\text { specimens }\end{array}$ & $\%$ \\
\hline $\begin{array}{l}\text { Incoming taxa: } \\
\text { Hornibrookina sp. cf. H. teuriensis } \\
\text { Persistent taxa: }\end{array}$ & 29 & 10.1 & 26 & 7.8 & 19 & 6.4 & 12 & 3.8 \\
\hline Biscutum castrorum & 44 & 15.4 & 52 & 15.7 & 28 & 9.4 & 34 & 10.9 \\
\hline Markalius inversus & 18 & 6.3 & 21 & 6.3 & 26 & 8.7 & 20 & 6.4 \\
\hline Neocrepidolithus cohenii & 8 & 2.8 & 11 & 3.3 & 10 & 3.3 & 5 & 1.6 \\
\hline Placozygus fibuliformis & 2 & 0.7 & 2 & 0.6 & 1 & 0.3 & & \\
\hline $\begin{array}{l}\text { Placozygus sigmoides } \\
\text { Vanishing taxa: }\end{array}$ & 34 & 11.9 & 82 & 24.7 & 46 & 15.4 & 60 & 19.2 \\
\hline Ahmuellerella octoradiata & 1 & 0.3 & 2 & 0.6 & 3 & 1.0 & 4 & 1.3 \\
\hline Arkhangelskiella cymbiformis & 9 & 3.1 & 6 & 1.8 & 5 & 1.7 & 10 & 3.2 \\
\hline Cretarhabdus spp. & 1 & 0.3 & 2 & 0.6 & 1 & 0.0 & 1 & 0.3 \\
\hline Cribrosphaerella ehrenbergii & 2 & 0.7 & 2 & 0.6 & 5 & 1.7 & 2 & 0.6 \\
\hline Eiffellithus turriseiffeli & 1 & 0.3 & & & 1 & 0.0 & 1 & 0.3 \\
\hline Glaukolithus fessus & 5 & 1.7 & 1 & 0.3 & 4 & 1.3 & 6 & 1.9 \\
\hline Kamptnerius magnificus & 8 & 2.8 & 5 & 1.5 & 12 & 4.0 & 10 & 3.2 \\
\hline Lucianorhabdus cayeuxii & 24 & 8.4 & 34 & 10.2 & 20 & 6.7 & 31 & 9.9 \\
\hline Microrhabdulus decoratus & & & & & & & 1 & 0.3 \\
\hline Micula staurophora & 3 & 1.0 & 1 & 0.3 & 2 & 0.7 & 4 & 1.3 \\
\hline Nephrolithus frequens & 18 & 6.3 & 8 & 2.4 & 30 & 10.0 & 27 & 8.6 \\
\hline Prediscosphaera cretacea & 6 & 2.1 & 8 & 2.4 & 13 & 4.3 & 15 & 4.8 \\
\hline Prediscosphaera spinosa & & & 1 & 0.3 & 3 & 1.0 & 4 & 1.3 \\
\hline Prediscosphaera stoveri & 62 & 21.7 & 46 & 13.9 & 61 & 20.4 & 53 & 16.9 \\
\hline Undetermined & 11 & 3.8 & 22 & 6.6 & 9 & 3.0 & 13 & 4.2 \\
\hline Sum & 286 & 100.0 & 332 & 100.0 & 299 & 99.3 & 313 & 100.0 \\
\hline
\end{tabular}




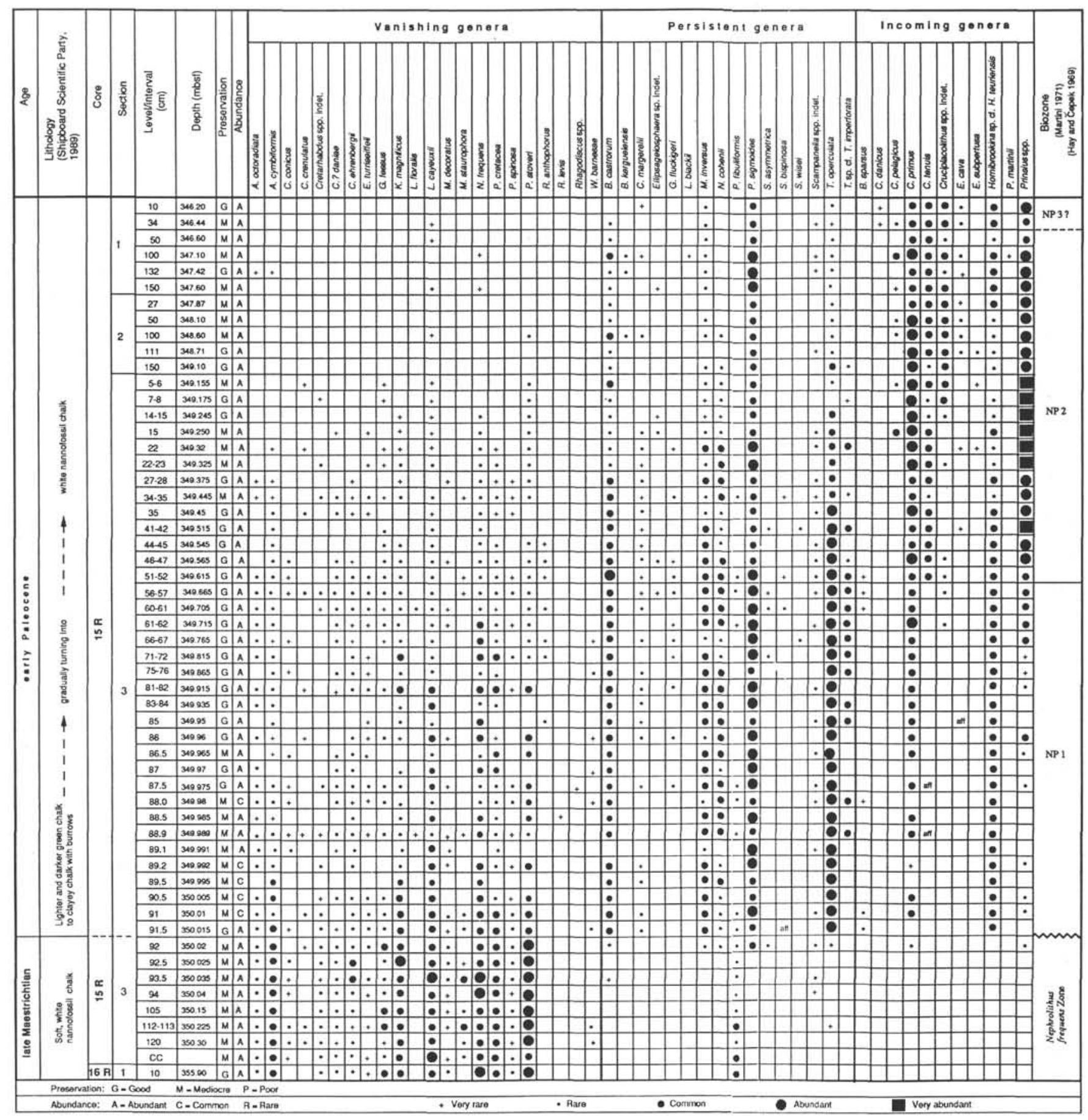

Figure 5. Distribution and frequency of calcareous nannofossil species across the Cretaceous/Paleocene boundary at Hole $750 \mathrm{~A}$. 


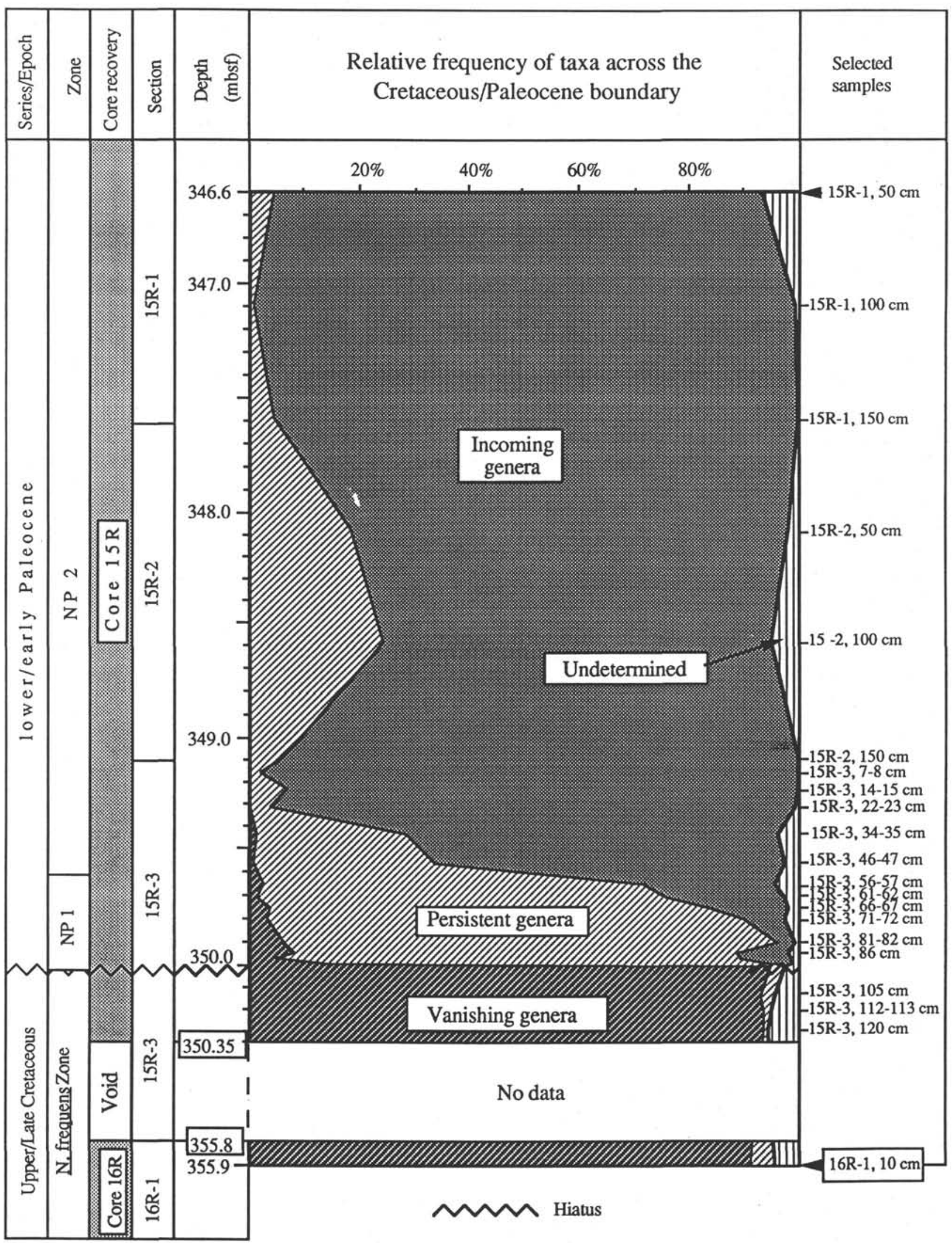

Figure 6. Percentage frequency of vanishing, persistent, and incoming genera at Hole 750A. Note the unconformity at 350.0 mbsf (at the Cretaceous/Paleocene boundary), and the $5.45 \mathrm{~m}$ coring gap between Cores $120-750 \mathrm{~A}-15 \mathrm{R}$ and $-16 \mathrm{R}$. 
Table 8. Abundance counts of calcareous nannofossils, except for Thoracosphaera and Prinsius spp., in the Maestrichtian and Paleocene chalks at Hole $750 \mathrm{~A}$.

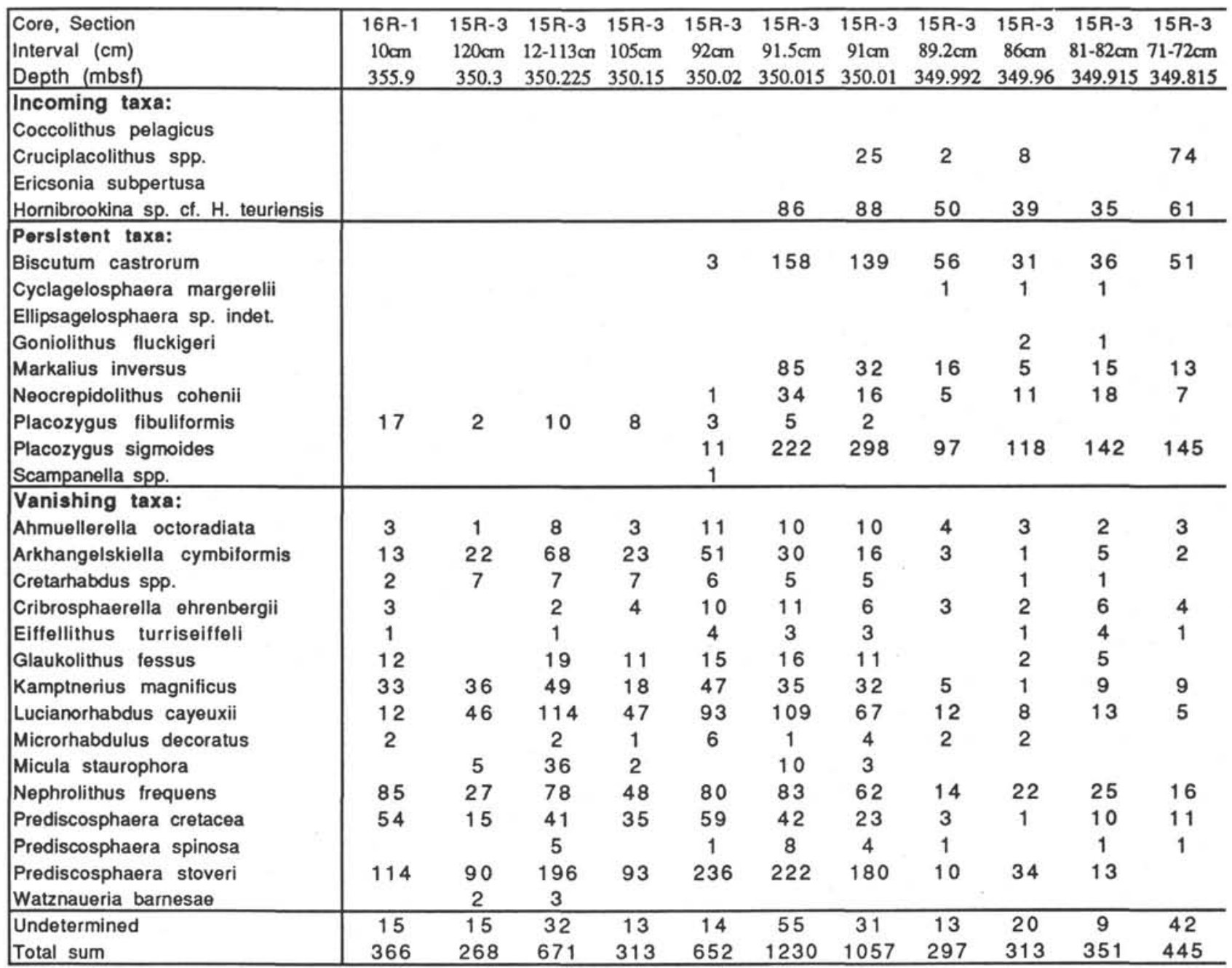


Table 8 (continued).

\begin{tabular}{|c|c|c|c|c|c|c|c|c|c|c|c|c|c|}
\hline 15R-3 & 15R-3 & $15 R-3$ & $15 R-3$ & $15 R-3$ & 15R-3 & $15 R-3$ & 15R-3 & 15R-2 & 15R-2 & $15 \mathrm{R}-2$ & $15 R-1$ & 15R-1 & 15R-1 \\
\hline $66-67 \mathrm{~cm}$ & $61-62 \mathrm{~cm}$ & $56-57 \mathrm{~cm}$ & $46-47 \mathrm{~cm}$ & $34-35 \mathrm{~cm}$ & $22-23 \mathrm{~cm}$ & $14-15 \mathrm{~cm}$ & $7-8 \mathrm{~cm}$ & $150 \mathrm{~cm}$ & $100 \mathrm{~cm}$ & $50 \mathrm{~cm}$ & $150 \mathrm{~cm}$ & $100 \mathrm{~cm}$ & $50 \mathrm{~cm}$ \\
\hline \multirow[t]{2}{*}{349.765} & 349.715 & 349.665 & 349.565 & 349.445 & 349.325 & 349.245 & 349.175 & 349.1 & 348.6 & 348.1 & 347.6 & 347.1 & 346.6 \\
\hline & & 1 & & & & 11 & 3 & 5 & 5 & 1 & 1 & 20 & 97 \\
\hline 22 & 66 & 87 & 139 & 227 & 191 & 226 & 239 & 246 & 195 & 252 & 88 & 104 & 58 \\
\hline 72 & 47 & 37 & 10 & 2 & & 1 & & & 2 & 5 & 18 & 12 & 2 \\
\hline \multirow[t]{3}{*}{48} & 47 & 47 & 34 & 17 & 6 & 6 & 8 & 6 & 15 & 4 & 9 & 16 & 2 \\
\hline & & & & 1 & 1 & 1 & & & & & & & \\
\hline & & 1 & 1 & & & 1 & & & & & 1 & & \\
\hline 7 & 12 & 15 & 6 & 6 & 8 & 1 & 1 & & & 1 & 3 & 5 & 3 \\
\hline 7 & 6 & 25 & 14 & 9 & 17 & 1 & 3 & 4 & 1 & & & & \\
\hline 196 & 232 & 145 & 93 & 54 & 83 & 53 & 48 & 45 & 63 & 68 & 152 & 100 & 33 \\
\hline \multicolumn{14}{|l|}{5} \\
\hline \multirow[t]{2}{*}{2} & 3 & 3 & 1 & & & & & & & & & & \\
\hline & & 2 & & 3 & 2 & & 1 & & & & & & \\
\hline \multirow[t]{2}{*}{3} & & 2 & 2 & 1 & & & & & & & & & \\
\hline & & 1 & & & & & & & & & & & \\
\hline 1 & 1 & 2 & & & 1 & & 1 & & & & & & \\
\hline 3 & 1 & 2 & 1 & & 2 & 1 & & & & & & & \\
\hline \multirow[t]{2}{*}{4} & 1 & 1 & & 1 & 1 & 1 & 1 & & 1 & & 11 & & 1 \\
\hline & 1 & & 1 & & & & & & & & & & \\
\hline 9 & 7 & 10 & 6 & 4 & 3 & 3 & & & & & 1 & 1 & \\
\hline \multirow[t]{3}{*}{4} & 1 & & 1 & & 2 & & & & & & & & \\
\hline & & & & 1 & & & & & & & & & \\
\hline & & & & & & 4 & 1 & & 1 & & & & 2 \\
\hline \multicolumn{14}{|l|}{1} \\
\hline 19 & 28 & 40 & 32 & 39 & 29 & 10 & 7 & 5 & 33 & 30 & 29 & 42 & 91 \\
\hline 403 & 453 & 421 & 341 & 365 & 346 & 320 & 313 & 311 & 316 & 361 & 313 & 300 & 295 \\
\hline
\end{tabular}




\section{T. EHRENDORFER, M.-P. AUBRY}

Table 9. Relative frequency (percentages) of taxa, except for Thoracosphaera and Prinsius spp., in the Maestrichtian and Paleocene chalks at Hole $750 \mathrm{~A}$.

\begin{tabular}{|c|c|c|c|c|c|c|c|c|c|c|c|}
\hline $\begin{array}{l}\text { Core, Section } \\
\text { Interval (cm) } \\
\text { Depth (mbsf) }\end{array}$ & $\begin{array}{c}16 \mathrm{R}-1 \\
10 \mathrm{~cm} \\
355.9 \\
\end{array}$ & $\begin{array}{l}15 \mathrm{R}-3 \\
120 \mathrm{~cm} \\
350.3 \\
\end{array}$ & $\begin{array}{c}15 R-3 \\
112-113 \mathrm{~cm} \\
350.225\end{array}$ & $\begin{array}{l}15 \mathrm{R}-3 \\
105 \mathrm{~cm} \\
350.15\end{array}$ & $\begin{array}{c}15 \mathrm{R}-3 \\
92 \mathrm{~cm} \\
350.02 \\
\end{array}$ & $\begin{array}{c}15 \mathrm{R}-3 \\
91.5 \mathrm{~cm} \\
350.015\end{array}$ & $\begin{array}{c}15 R-3 \\
91 \mathrm{~cm} \\
350.01 \\
\end{array}$ & $\begin{array}{c}15 \mathrm{R}-3 \\
89.2 \mathrm{~cm} \\
349.992 \\
\end{array}$ & $\begin{array}{c}15 R-3 \\
86 \mathrm{~cm} \\
349.96 \\
\end{array}$ & $\begin{array}{c}15 R-3 \\
81-82 \mathrm{~cm} \\
349.915 \\
\end{array}$ & $\begin{array}{c}15 \mathrm{R}-3 \\
71-72 \mathrm{~cm} \\
349.815 \\
\end{array}$ \\
\hline Incoming taxa: & & & & & & & & & & & \\
\hline Coccolithus pelagicus & 0.0 & 0.0 & 0.0 & 0.0 & 0.0 & 0.0 & 0.0 & 0.0 & 0.0 & 0.0 & 0.0 \\
\hline Cruciplacolithus spp. & 0.0 & 0.0 & 0.0 & 0.0 & 0.0 & 0.0 & 2.4 & 0.7 & 2.6 & 0.0 & 16.6 \\
\hline Ericsonia subpertusa & 0.0 & 0.0 & 0.0 & 0.0 & 0.0 & 0.0 & 0.0 & 0.0 & 0.0 & 0.0 & 0.0 \\
\hline Hornibrookina sp. cf. H. teuriensis & 0.0 & 0.0 & 0.0 & 0.0 & 0.0 & 7.0 & 8.3 & 16.8 & 12.5 & 10.0 & 13.7 \\
\hline $\begin{array}{l}\text { Persistent taxa: } \\
\text { Biscutum castrorum }\end{array}$ & 0 & 0 & 0.0 & & & 12.8 & 13.2 & 18.9 & & & 1 \\
\hline Cyclagelosphaera margerelii & 0.0 & 0.0 & 0.0 & 0.0 & 0.0 & 0.0 & 0.0 & 0.3 & 0.3 & 0.3 & 0.0 \\
\hline Ellipsagelosphaera sp. indet. & 0.0 & 0.0 & 0.0 & 0.0 & 0.0 & 0.0 & 0.0 & 0.0 & 0.0 & 0.0 & 0.0 \\
\hline Goniolithus fluckigeri & 0.0 & 0.0 & 0.0 & 0.0 & 0.0 & 0.0 & 0.0 & 0.0 & 0.6 & 0.3 & 0.0 \\
\hline Markalius inversus & 0.0 & 0.0 & 0.0 & 0.0 & 0.0 & 6.9 & 3.0 & 5.4 & 1.6 & 4.3 & 2.9 \\
\hline Neocrepidolithus cohenii & 0.0 & 0.0 & 0.0 & 0.0 & 0.2 & 2.8 & 1.5 & 1.7 & 3.5 & 5.1 & 1.6 \\
\hline Placozygus fibuliformis & 4.6 & 0.7 & 1.5 & 2.6 & 0.5 & 0.4 & 0.2 & 0.0 & 0.0 & 0.0 & 0.0 \\
\hline Placozygus sigmoides & 0.0 & 0.0 & 0.0 & 0.0 & 1.7 & 18.0 & 28.2 & 32.7 & 37.7 & 40.5 & 32.6 \\
\hline Scampanella spp. & 0.0 & 0.0 & 0.0 & 0.0 & 0.2 & 0.0 & 0.0 & 0.0 & 0.0 & 0.0 & 0.0 \\
\hline Vanishing taxa: & & & & & & & & & & & \\
\hline Ahmuellerella octoradiata & 0.8 & 0.4 & 1.2 & 1.0 & 1.7 & 0.8 & 0.9 & 1.3 & 1.0 & 0.6 & 0.7 \\
\hline Arkhangelskiella cymbiformis & 3.6 & 8.2 & 10.1 & 7.3 & 7.8 & 2.4 & 1.5 & 1.0 & 0.3 & 1.4 & 0.4 \\
\hline Cretarhabdus spp. & 0.5 & 2.6 & 1.0 & 2.2 & 0.9 & 0.4 & 0.5 & 0.0 & 0.3 & 0.3 & 0.0 \\
\hline Cribrosphaerella ehrenbergii & 0.8 & 0.0 & 0.3 & 1.3 & 1.5 & 0.9 & 0.6 & 1.0 & 0.6 & 1.7 & 0.9 \\
\hline Eiffellithus turriseiffeli & 0.3 & 0.0 & 0.1 & 0.0 & 0.6 & 0.2 & 0.3 & 0.0 & 0.3 & 1.1 & 0.2 \\
\hline Glaukolithus fessus & 3.3 & 0.0 & 2.8 & 3.5 & 2.3 & 1.3 & 1.0 & 0.0 & 0.6 & 1.4 & 0.0 \\
\hline Kamptnerius magnificus & 9.0 & 13.4 & 7.3 & 5.8 & 7.2 & 2.8 & 3.0 & 1.7 & 0.3 & 2.6 & 2.0 \\
\hline Lucianorhabdus cayeuxii & 3.3 & 17.2 & 17.0 & 15.0 & 14.3 & 8.9 & 6.3 & 4.0 & 2.6 & 3.7 & 1.1 \\
\hline Microrhabdulus decoratus & 0.5 & 0.0 & 0.3 & 0.3 & 0.9 & 0.1 & 0.4 & 0.7 & 0.6 & 0.0 & 0.0 \\
\hline Micula staurophora & 0.0 & 1.9 & 5.4 & 0.6 & 0.0 & 0.8 & 0.3 & 0.0 & 0.0 & 0.0 & 0.0 \\
\hline Nephrolithus frequens & 23.2 & 10.1 & 11.6 & 15.3 & 12.3 & 6.7 & 5.9 & 4.7 & 7.0 & 7.1 & 3.6 \\
\hline Prediscosphaera cretacea & 14.8 & 5.6 & 6.1 & 11.2 & 9.0 & 3.4 & 2.2 & 1.0 & 0.3 & 2.8 & 2.5 \\
\hline Prediscosphaera spinosa & 0.0 & 0.0 & 0.7 & 0.0 & 0.2 & 0.7 & 0.4 & 0.3 & 0.0 & 0.3 & 0.2 \\
\hline Prediscosphaera stoveri & 31.1 & 33.6 & 29.2 & 29.7 & 36.2 & 18.0 & 17.0 & 3.4 & 10.9 & 3.7 & 0.0 \\
\hline Watznaueria barnesae & 0.0 & 0.7 & 0.4 & 0.0 & 0.0 & 0.0 & 0.0 & 0.0 & 0.0 & 0.0 & 0.0 \\
\hline Undetermined & 4.1 & 5.6 & 4.8 & 4.2 & 2.1 & 4.5 & 2.9 & 4.4 & 6.4 & 2.6 & 9.4 \\
\hline Total sum & 100.0 & 100.0 & 100.0 & 100.0 & 100.0 & 100.0 & 100.0 & 100.0 & 100.0 & 100.0 & 100.0 \\
\hline
\end{tabular}


Table 9 (continued).

\begin{tabular}{|c|c|c|c|c|c|c|c|c|c|c|c|c|c|}
\hline 15R-3 & 15R-3 & 15R-3 & $15 R-3$ & 15R-3 & 15R-3 & $15 R-3$ & $15 R-3$ & $15 R-2$ & 15R-2 & $15 R-2$ & 15R-1 & $15 R-1$ & $15 R-1$ \\
\hline $66-67 \mathrm{~cm}$ & $61-62 \mathrm{~cm}$ & $56-57 \mathrm{~cm}$ & $46-47 \mathrm{~cm}$ & $34-35 \mathrm{~cm}$ & $22-23 \mathrm{~cm}$ & $14-15 \mathrm{~cm}$ & $7-8 \mathrm{~cm}$ & $150 \mathrm{~cm}$ & $100 \mathrm{~cm}$ & $50 \mathrm{~cm}$ & $150 \mathrm{~cm}$ & $100 \mathrm{~cm}$ & $50 \mathrm{~cm}$ \\
\hline 349.765 & 349.715 & 349.665 & 349.565 & 349.445 & 349.325 & 349.245 & 349.175 & 349.1 & 348.6 & 348.1 & 347.6 & 347.1 & 346.6 \\
\hline 0.0 & 0.0 & 0.2 & 0.0 & 0.0 & 0.0 & 3.4 & 1.0 & 1.6 & 1.6 & 0.3 & 0.3 & 6.7 & 32.9 \\
\hline 5.5 & 14.6 & 20.7 & 40.8 & 62.2 & 55.2 & 70.6 & 76.4 & 79.1 & 61.7 & 69.8 & 28.1 & 34.7 & 19.7 \\
\hline 0.0 & 0.0 & 0.0 & 0.0 & 0.0 & 0.0 & 0.0 & 0.0 & 0.0 & 0.0 & 0.0 & 0.0 & 0.0 & 2.0 \\
\hline 17.9 & 10.4 & 8.8 & 2.9 & 0.5 & 0.0 & 0.3 & 0.0 & 0.0 & 0.6 & 1.4 & 5.8 & 4.0 & 0.7 \\
\hline 11.9 & 10.4 & 11.2 & 10.0 & 4.7 & 1.7 & 1.9 & 2.6 & 1.9 & 4.7 & 1.1 & 2.9 & 5.3 & 0.7 \\
\hline 0.0 & 0.0 & 0.0 & 0.0 & 0.3 & 0.3 & 0.3 & 0.0 & 0.0 & 0.0 & 0.0 & 0.0 & 0.0 & 0.0 \\
\hline 0.0 & 0.0 & 0.2 & 0.3 & 0.0 & 0.0 & 0.3 & 0.0 & 0.0 & 0.0 & 0.0 & 0.3 & 0.0 & 0.0 \\
\hline 0.0 & 0.0 & 0.0 & 0.0 & 0.0 & 0.0 & 0.0 & 0.0 & 0.0 & 0.0 & 0.0 & 0.0 & 0.0 & 0.0 \\
\hline 1.7 & 2.6 & 3.6 & 1.8 & 1.6 & 2.3 & 0.3 & 0.3 & 0.0 & 0.0 & 0.3 & 1.0 & 1.7 & 1.0 \\
\hline 1.7 & 1.3 & 5.9 & 4.1 & 2.5 & 4.9 & 0.3 & 1.0 & 1.3 & 0.3 & 0.0 & 0.0 & 0.0 & 0.0 \\
\hline 0.0 & 0.0 & 0.0 & 0.0 & 0.0 & 0.0 & 0.0 & 0.0 & 0.0 & 0.0 & 0.0 & 0.0 & 0.0 & 0.0 \\
\hline 48.6 & 51.2 & 34.4 & 27.3 & 14.8 & 24.0 & 16.6 & 15.3 & 14.5 & 19.9 & 18.8 & 48.6 & 33.3 & 11.2 \\
\hline 0.0 & 0.0 & 0.0 & 0.0 & 0.0 & 0.0 & 0.0 & 0.0 & 0.0 & 0.0 & 0.0 & 0.0 & 0.0 & 0.0 \\
\hline 1.2 & 0.0 & 0.0 & 0.0 & 0.0 & 0.0 & 0.0 & 0.0 & 0.0 & 0.0 & 0.0 & 0.0 & 0.0 & 0.0 \\
\hline 0.5 & 0.7 & 0.7 & 0.3 & 0.0 & 0.0 & 0.0 & 0.0 & 0.0 & 0.0 & 0.0 & 0.0 & 0.0 & 0.0 \\
\hline 0.0 & 0.0 & 0.5 & 0.0 & 0.8 & 0.6 & 0.0 & 0.3 & 0.0 & 0.0 & 0.0 & 0.0 & 0.0 & 0.0 \\
\hline 0.7 & 0.0 & 0.5 & 0.6 & 0.3 & 0.0 & 0.0 & 0.0 & 0.0 & 0.0 & 0.0 & 0.0 & 0.0 & 0.0 \\
\hline 0.0 & 0.0 & 0.2 & 0.0 & 0.0 & 0.0 & 0.0 & 0.0 & 0.0 & 0.0 & 0.0 & 0.0 & 0.0 & 0.0 \\
\hline 0.2 & 0.2 & 0.5 & 0.0 & 0.0 & 0.3 & 0.0 & 0.3 & 0.0 & 0.0 & 0.0 & 0.0 & 0.0 & 0.0 \\
\hline 0.7 & 0.2 & 0.5 & 0.3 & 0.0 & 0.6 & 0.3 & 0.0 & 0.0 & 0.0 & 0.0 & 0.0 & 0.0 & 0.0 \\
\hline 1.0 & 0.2 & 0.2 & 0.0 & 0.3 & 0.3 & 0.3 & 0.3 & 0.0 & 0.3 & 0.0 & 3.5 & 0.0 & 0.3 \\
\hline 0.0 & 0.2 & 0.0 & 0.3 & 0.0 & 0.0 & 0.0 & 0.0 & 0.0 & 0.0 & 0.0 & 0.0 & 0.0 & 0.0 \\
\hline 0.0 & 0.0 & 0.0 & 0.0 & 0.0 & 0.0 & 0.0 & 0.0 & 0.0 & 0.0 & 0.0 & 0.0 & 0.0 & 0.0 \\
\hline 2.2 & 1.5 & 2.4 & 1.8 & 1.1 & 0.9 & 0.9 & 0.0 & 0.0 & 0.0 & 0.0 & 0.3 & 0.3 & 0.0 \\
\hline 1.0 & 0.2 & 0.0 & 0.3 & 0.0 & 0.6 & 0.0 & 0.0 & 0.0 & 0.0 & 0.0 & 0.0 & 0.0 & 0.0 \\
\hline 0.0 & 0.0 & 0.0 & 0.0 & 0.3 & 0.0 & 0.0 & 0.0 & 0.0 & 0.0 & 0.0 & 0.0 & 0.0 & 0.0 \\
\hline 0.0 & 0.0 & 0.0 & 0.0 & 0.0 & 0.0 & 1.3 & 0.3 & 0.0 & 0.3 & 0.0 & 0.0 & 0.0 & 0.7 \\
\hline 0.2 & 0.0 & 0.0 & 0.0 & 0.0 & 0.0 & 0.0 & 0.0 & 0.0 & 0.0 & 0.0 & 0.0 & 0.0 & 0.0 \\
\hline 4.7 & 6.2 & 9.5 & 9.4 & 10.7 & 8.4 & 3.1 & 2.2 & 1.6 & 10.4 & 8.3 & 9.3 & 14.0 & 30.8 \\
\hline 100.0 & 100.0 & 100.0 & 100.0 & 100.0 & 100.0 & 100.0 & 100.0 & 100.0 & 100.0 & 100.0 & 100.0 & 100.0 & 100.0 \\
\hline
\end{tabular}




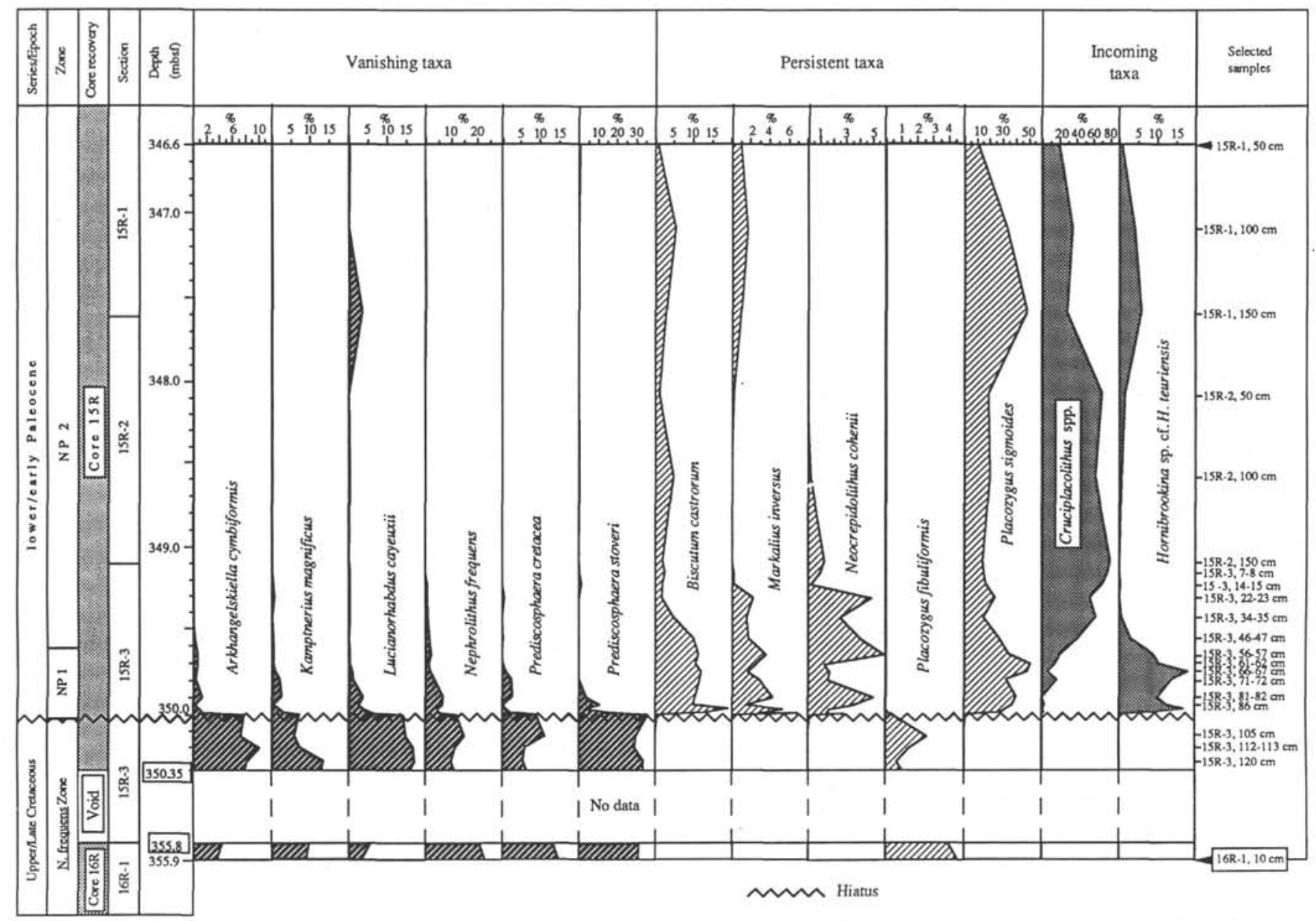

Figure 7. Percentage frequency of selected species of the vanishing, persistent, and incoming genera at Hole $750 \mathrm{~A}$. 


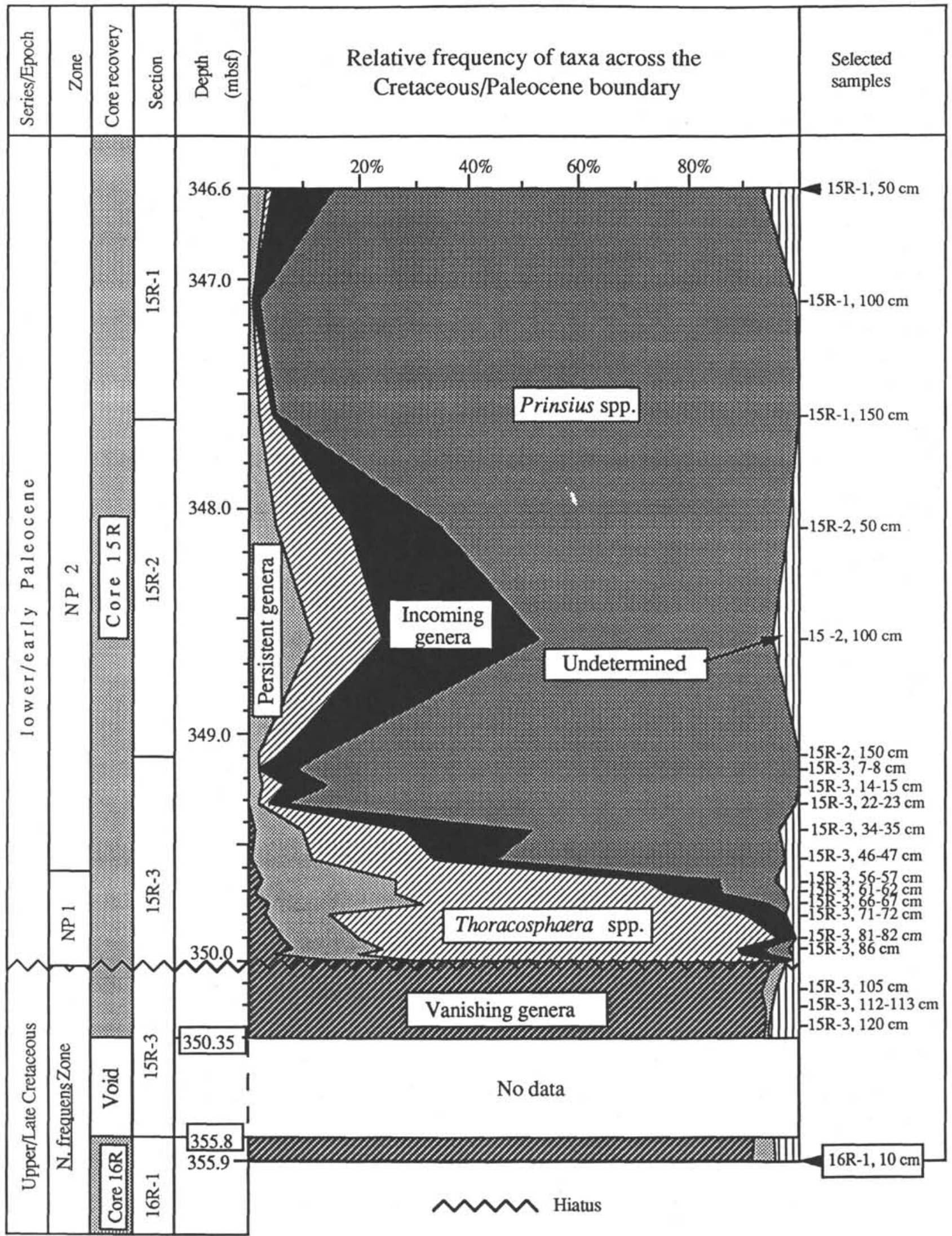

Figure 8. Percentage frequency of vanishing, persistent, and incoming genera at Hole $750 \mathrm{~A}$, with emphasis on the frequency of Thoracosphaera (a persistent genus) and Prinsius (a representative of the incoming genera). Note the unconformity at 350.0 mbsf (at the Cretaceous/Paleocene boundary), and the $5.45-\mathrm{m}$ coring gap between Cores $120-750 \mathrm{~A}-15 \mathrm{R}$ and $-16 \mathrm{R}$. 


\section{T. EHRENDORFER, M.-P. AUBRY}

Table 10. Abundance counts (number of specimens) and relative frequency (percentages) of Thoracosphaera and Prinsius spp., in the Maestrichtian and Paleocene chalks at Hole 750A.

\begin{tabular}{|c|c|c|c|c|c|c|c|c|c|c|}
\hline Core, Section & $16 R-1$ & $15 R-3$ & $15 R-3$ & $15 R-3$ & $15 R-3$ & $15 R-3$ & $15 R-3$ & $15 R-3$ & $15 R-3$ & 15R-3 \\
\hline Interval $(\mathrm{cm})$ & $10 \mathrm{~cm}$ & $120 \mathrm{~cm}$ & $112-113 \mathrm{~cm}$ & $105 \mathrm{~cm}$ & $92 \mathrm{~cm}$ & $91.5 \mathrm{~cm}$ & $91 \mathrm{~cm}$ & $89.2 \mathrm{~cm}$ & $86 \mathrm{~cm}$ & $81-82 \mathrm{~cm}$ \\
\hline Depth (mbsf) & 355.9 & 350.3 & 350.225 & 350.15 & 350.02 & 350.015 & 350.01 & 349.992 & 349.96 & 349.915 \\
\hline Thoracosphaera spp. & 0 & 0 & 0 & 0 & 0 & 205 & 187 & 30 & 59 & 91 \\
\hline All other Nannofossils & & & & & & 105 & 97 & 11 & 28 & 27 \\
\hline Prinsius spp. & 0 & 0 & 0 & 0 & 0 & 0 & 0 & 2 & 4 & 1 \\
\hline \multicolumn{11}{|l|}{ Number of specimens: } \\
\hline Vanishing taxa & 334 & 251 & 629 & 292 & 619 & 585 & 426 & 57 & 78 & 94 \\
\hline Persistent taxa (excl. Thoracosphaera) & 17 & 2 & 10 & 8 & 19 & 504 & 487 & 175 & 168 & 213 \\
\hline Thoracosphaera spp. & 0 & 0 & 0 & 0 & 0 & 2401 & 2038 & 810 & 660 & 1183 \\
\hline Incoming taxa (excl. Prinsius spp.) & 0 & 0 & 0 & 0 & 0 & 86 & 113 & 52 & 47 & 35 \\
\hline Prinsius spp. & 0 & 0 & 0 & 0 & 0 & 0 & 0 & 54 & 45 & 13 \\
\hline Undetermined & 15 & 15 & 32 & 13 & 14 & 55 & 31 & 13 & 20 & 9 \\
\hline Sum & 366 & 268 & 671 & 313 & 652 & 3631 & 3095 & 1161 & 1017 & 1547 \\
\hline \multicolumn{11}{|l|}{ Percentage of taxa: } \\
\hline Vanishing taxa & 91.3 & 93.7 & 93.7 & 93.3 & 94.9 & 16.1 & 13.8 & 4.9 & 7.7 & 6.1 \\
\hline Persistent taxa (excl. Thoracosphaera) & 4.6 & 0.7 & 1.5 & 2.6 & 2.9 & 13.9 & 15.7 & 15.1 & 16.5 & 13.8 \\
\hline Thoracosphaera spp. & 0.0 & 0.0 & 0.0 & 0.0 & 0.0 & 66.1 & 65.8 & 69.8 & 64.8 & 76.5 \\
\hline Incoming taxa (excl. Prinsius spp.) & 0.0 & 0.0 & 0.0 & 0.0 & 0.0 & 2.4 & 3.7 & 4.5 & 4.6 & 2.3 \\
\hline Prinsius spp. & 0.0 & 0.0 & 0.0 & 0.0 & 0.0 & 0.0 & 0.0 & 4.7 & 4.4 & 0.8 \\
\hline Undetermined & 4.1 & 5.6 & 4.8 & 4.2 & 2.1 & 1.5 & 1.0 & 1.1 & 2.0 & 0.6 \\
\hline Sum & 100.0 & 100.0 & 100.0 & 100.0 & 100.0 & 100.0 & 100.0 & 100.0 & 100.0 & 100.0 \\
\hline
\end{tabular}

Table 10 (continued).

\begin{tabular}{|c|c|c|c|c|c|c|c|c|c|c|c|c|c|c|}
\hline $15 R-3$ & $15 R-3$ & $15 \mathrm{R}-3$ & $15 R-3$ & $15 R-3$ & $15 R-3$ & $15 R-3$ & $15 R-3$ & 15R-3 & 15R-2 & 15R-2 & 15R-2 & 15R-1 & 15R-1 & 15R-1 \\
\hline $71-72 \mathrm{~cm}$ & $66-67 \mathrm{~cm}$ & $61-62 \mathrm{~cm}$ & $56-57 \mathrm{~cm}$ & $46-47 \mathrm{~cm}$ & $34-35 \mathrm{~cm}$ & $22-23 \mathrm{~cm}$ & $14-15 \mathrm{~cm}$ & $7-8 \mathrm{~cm}$ & $150 \mathrm{~cm}$ & $100 \mathrm{~cm}$ & $50 \mathrm{~cm}$ & $150 \mathrm{~cm}$ & $100 \mathrm{~cm}$ & $50 \mathrm{~cm}$ \\
\hline 349.815 & 349.765 & 349.715 & 349.665 & 349.565 & 349.445 & 349.325 & 349.245 & 349.175 & 349.1 & 348.6 & 348.1 & 347.6 & 347.1 & 346.6 \\
\hline 75 & 46 & 38 & 39 & 19 & 16 & 2 & 6 & 0 & 3 & 5 & 8 & 2 & 0 & 1 \\
\hline 24 & 38 & 30 & 37 & 21 & 31 & 6 & 13 & 8 & 6 & 18 & 14 & 3 & 3 & 16 \\
\hline 0 & 3 & 9 & 9 & 45 & 38 & 109 & 118 & 84 & 58 & 17 & 38 & 88 & 143 & 61 \\
\hline 52 & 32 & 15 & 23 & 12 & 10 & 11 & 9 & 4 & 0 & 2 & 0 & 12 & 1 & 3 \\
\hline 216 & 258 & 297 & 233 & 148 & 87 & 115 & 63 & 60 & 55 & 79 & 73 & 165 & 121 & 38 \\
\hline 1391 & 488 & 574 & 444 & 309 & 188 & 115 & 148 & 0 & 156 & 88 & 206 & 209 & 0 & 18 \\
\hline 135 & 94 & 113 & 125 & 149 & 229 & 191 & 238 & 242 & 251 & 202 & 258 & 107 & 136 & 163 \\
\hline 0 & 32 & 136 & 102 & 731 & 447 & 6286 & 2905 & 3287 & 3006 & 298 & 980 & 9181 & 14300 & 1125 \\
\hline 42 & 19 & 28 & 40 & 32 & 39 & 29 & 10 & 7 & 5 & 33 & 30 & 29 & 42 & 91 \\
\hline 1836 & 923 & 1163 & 967 & 1380 & 1001 & 6747 & 3372 & 3600 & 3473 & 702 & 1547 & 9703 & 14600 & 1438 \\
\hline 2.8 & 3.5 & 1.3 & 2.4 & 0.9 & 1.0 & 0.2 & 0.3 & 0.1 & 0.0 & 0.3 & 0.0 & 0.1 & 0.0 & 0.2 \\
\hline 11.8 & 28.0 & 25.5 & 24.1 & 10.7 & 8.7 & 1.7 & 1.9 & 1.7 & 1.6 & 11.3 & 4.7 & 1.7 & 0.8 & 2.6 \\
\hline 75.8 & 52.9 & 49.4 & 45.9 & 22.4 & 18.8 & 1.7 & 4.4 & 0.0 & 4.5 & 12.5 & 13.3 & 2.2 & 0.0 & 1.3 \\
\hline 7.4 & 10.2 & 9.7 & 12.9 & 10.8 & 22.9 & 2.8 & 7.1 & 6.7 & 7.2 & 28.8 & 16.7 & 1.1 & 0.9 & 11.3 \\
\hline 0.0 & 3.4 & 11.7 & 10.6 & 52.9 & 44.7 & 93.2 & 86.1 & 91.3 & 86.6 & 42.5 & 63.3 & 94.6 & 97.9 & 78.2 \\
\hline 2.3 & 2.1 & 2.4 & 4.1 & 2.3 & 3.9 & 0.4 & 0.3 & 0.2 & 0.1 & 4.7 & 1.9 & 0.3 & 0.3 & 6.3 \\
\hline 100.0 & 100.0 & 100.0 & 100.0 & 100.0 & 100.0 & 100.0 & 100.0 & 100.0 & 100.0 & 100.0 & 100.0 & 100.0 & 100.0 & 100.0 \\
\hline
\end{tabular}

